Pamiętnik Literacki 2013, 3, s. 119-143
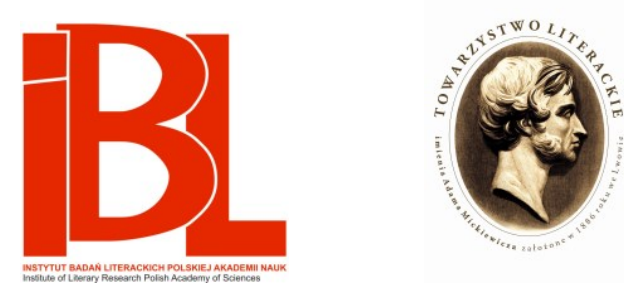

Dramaturgia Jana Bielskiego na tle przemian w teatrze jezuickim w XVIII wieku

\author{
Małgorzata Mieszek
}


Pamiętnik Literacki CIV, 2013, z. 3

PL ISSN 0031-0514

\section{MAŁGORZATA MIESZEK}

(Uniwersytet Łódzki)

\section{DRAMATURGIA JANA BIELSKIEGO NA TLE PRZEMIAN W TEATRZE JEZUICKIM W XVIII WIEKU}

Jan Bielski (1717-1768) należy do pokolenia autorów jezuickich, którzy odegrali doniosłą rolę w kształtowaniu nowego oblicza teatru szkolnego. Ich działalność przypadła na czas między barokiem a - rodzącym się dopiero - oświeceniem. Co więcej, byli oni świadkami i aktywnymi współuczestnikami procesu reform w szkolnictwie jezuickim. Również Bielskiego określano mianem ,jezuity nowego typu” oraz mianem ,,przewodnika nowego kierunku”, choć dostrzegano w jego twórczości także elementy odziedziczone po XVII wieku ${ }^{1}$. Wielu badaczy uznało, iż autor stał - by posłużyć się sformułowaniem Stanisława Załęskiego - „,na przełomie”2. Większość swego życia związał Bielski z kolegium poznańskim, a więc jedną z istotniejszych placówek jezuickich w dawnej Rzeczypospolitej. Owe zachodzące wówczas przemiany ideowe, świadomościowe i kulturowe zaważyły niewątpliwie na kształcie twórczości jezuity.

Reforma szkolnictwa jezuickiego przebiegała stopniowo i miała na celu zmodernizowanie procesu edukacyjnego. Najczęściej podawaną cezurą oddzielającą czasy stare od nowych jest połowa XVIII stulecia. Trzeba jednak przypomnieć, że pewne symptomy nowych tendencji ujawniły się już pod koniec w. XVII, a później szczególnie w latach trzydziestych i czterdziestych XVIII stulecia ${ }^{3}$. Przemiany te

1 Zob. T. Grabow s ki, Ze studiów nad teatrem jezuickim we Francji $i$ w Polsce $w$ wiekach XVI-XVIII. Poznań 1963, s. 24. - I. K a d u 1 s k a, Ze studiów nad dramatem jezuickim wczesnego oświecenia (1746-1765). Wrocław 1974, s. 16. Dalej do owej pozycji odsyłam skrótem KZ. Prócz tego stosuję skróty na oznaczenie innych prac autorki: KP = Publiczność szkolnego teatru jezuickiego w XVIII wieku. W kręu regut, norm i praktyk. W zb.: Publiczność literacka i teatralna w dawnej Polsce. Red. H. Dziechcińska. Warszawa-Lódź 1985; KW = wstęp w zb.: Teatr jezuicki XVIII i XIX wieku w Polsce. Z antologia dramatu. Oprac. I. K a d u ls k a. Gdańsk 1997. Ponadto w artykule występują skróty do pism B. J u d k ow i a k: JP = Poznańska szkoła jezuicka nowego dramatopisania w połowie XVIII wieku. „Kronika Miasta Poznania” 2006, nr 4; JT = Teatr i dramat jezuitów. Jw., 2000, nr 3. Stosuję tu także skrót P = S. P i e tr a s z k o, Doktryna literacka polskiego klasycyzmu. Wrocław 1966. Liczby po skrótach wskazują stronice.

2 S. Z ał ę s k i, Jezuici w Polsce. T. 3: Prace misyjne nad ludem 1648-1773, cz. 2: 1700-1773. Lwów 1902, s. 1123.

3 Zob. np. J. P o p lat e k, Studia z dziejów jezuickiego teatru szkolnego w Polsce. Wstęp J. L e wański. Wrocław 1957, s. 11. Według J. L e wa ński e go (W teatrach staropolskich. W zb.: Dramaty staropolskie. Antologia. Oprac. ... T. 1. Przypisy M. B o k s z c z a n i n. Warszawa 1959, s. 64, 75) okres ożywienia w rozwoju dramatu jezuitów rozpoczął się od lat trzydzie- 
dotyczyły różnych dziedzin. Wprowadzano nowe przedmioty, a dotychczasowe modyfikowano. Porządkowano biblioteki poprzez uzupełnianie i aktualizowanie księgozbiorów. Modernizowano bazę podręczników i zwiększano ich nakłady. Nastąpił rozwój nauk matematycznych, architektury, astronomii oraz fizyki. W kolegium poznańskim, z którym przez wiele lat związany był Bielski, znajdowała się dobrze wyposażona pracownia nauk ścisłych, a Józef Rogaliński prowadził tam wykłady z fizyki doświadczalnej ${ }^{4}$. W kolegiach jezuickich zaczęto systematycznie uczyć historii ${ }^{5}$ oraz geografii. Do programu weszła też nauka zachodnich języków nowożytnych (francuskiego i niemieckiego). Upowszechniano również czytelnictwo w językach obcych. Ważne dla przebiegu reform było także kształcenie się nauczycieli w ośrodkach zagranicznych (m.in. w Paryżu, Lyonie, Marsylii, Wiedniu, Pradze, Rzymie czy Neapolu) ${ }^{6}$.

Również w teatrze, który był integralną częścią edukacji zakonnej, nastąpiły

stych w. XVIII, choć, jak dalej badacz zauważa, „dopiero zwrot ku regularnej tragedii i komedii w połowie wieku XVIII ma znamiona postępu i idzie po linii równoległej do owoczesnego przewrotu umysłowego i ideologicznego w Polsce”. P i e tra s z k o (P 202) zaobserwował ,pewne ożywienie" w dramatach jezuickich od lat czterdziestych XVIII wieku. Podobnie też T. K o s tk i e wic z o w a (Klasycyzm, sentymentalizm, rokoko. Szkice o prąach literackich polskiego oświecenia. Warszawa 1975, s. 21; Tendencje klasycystyczne w literaturze polskiej lat 1740-1765. W zb.: Studien zur polnischen Literatur-, Sprach- und Kulturgeschichte im 18. Jahrhundert. Vorträge der 3. deutsch-polnischen Polonistenkonferenz, Tübingen, April 1991. Hrsg. I. K u n e r t. Köln 1993), według której pojawiły się wówczas w Polsce wyraziste tendencje klasycystyczne. Dla Kadulsk i ej (KW 24) punktem zwrotnym w rozwoju dramatu jezuickiego był rok 1746, kiedy ukazała się po raz pierwszy tragedia S. J a w or s k i e g o Jonatas (Kalisz 1746. Dalej odsyłam do przedruku w zb.: Teatr jezuicki XVIII i XIX wieku w Polsce). Był to utwór nowego typu, a Przestroga do Czytelnika odzwierciedlała myślenie w duchu oświeceniowym. J u dk o w i a k (JT 34) dodała zaś, że owa przedmowa zapoczątkowała „etap świadomego respektowania zaleceń klasycystycznych w dramacie szkolnym". M. N i e c i k o w s k a (Teatr jezuicki w Wilnie $w 2$ połowie XVIII w. W zb.: Wilno teatralne. Red. M. Kozłowska. Warszawa 1998, s. 39) uznała natomiast, iż pierwsze symptomy przemian w teatrze jezuickim przypadły na początek w. XVIII, ale rzeczywiste zmiany zaczęły następować dopiero od połowy stulecia za sprawą konkurencyjnych pijarów.

4 Zob. S. B e d n a rs k i, Upadek $i$ odrodzenie szkót jezuickich $w$ Polsce. Studium z dziejów kultury i szkolnictwa polskiego. Kraków 1933, s. 57, 81-84, 338-374 (Reprint: Kraków 2003). L. P i e c h n i k: Działalność jezuitów na polu szkolnictwa w Poznaniu. „Nasza Przeszłość” t. 30 (1969), s. 199-200; Przemiany w szkolnictwie jezuickim w Polsce XVIII w. „Roczniki Humanistyczne" 1977, z. 2. - T. B i eń k o w s k i, Na przełomie epok. Edukacja na ziemiach polskich w latach 1720-1740. „Rozprawy z Dziejów Oświaty” t. 37 (1996), s. 55. - F. P a 1 u s z k i e w i c z, Szkolnictwo jezuickie w Rzeczpospolitej Obojga Narodów. „Przegląd Powszechny” 1998, nr 9, s. 240. J. F la g a, Z problematyki szkolnictwa publicznego zakonów $w$ Rzeczypospolitej $w$ drugiej połowie XVIII wieku. „Roczniki Humanistyczne” 2000, z. 2, s. 138, 143.

${ }_{5}$ Jak pisze K. Puchow ski (Nauczanie historii w polskich kolegiach jezuickich 〈15651773〉. Zarys problematyki. W zb.: Jezuici a kultura polska. Materiały sympozjum z okazji jubileuszu 500-lecia urodzin Ignacego Loyoli 〈1491-1991〉 i 450-lecia powstania Towarzystwa Jezusowego 〈1540-1990〉, Kraków, 15-17 lutego 1991 r. Red. L. Grzebień, S. Obirek. Kraków 1993, s. 290-295), od połowy XVIII w. nauczanie historii stało się powszechne, a dzięki polonizacji kadr uwypuklano w edukacji historycznej elementy rodzime. Za istotne uznano bowiem dostosowanie programu nauczania do życia państwa.

6 Zob. B e d narski, op. cit., s. 57-63, 249-252. - I. K a d u 1 s k a: Miejsce Franciszka Bohomolca w osiagnięciach teatru jezuickiego. W: Jezuici a kultura polska, s. 113; KW 24. R. W. W oł o s z y ń s k i, Między tradycją a reforma. Nauczyciele w Polsce XVIII wieku. Piotrków Trybunalski 2000, s. 11-44. - L. G r z e b i e ń, Czy Stanisław Konarski SP byt natchnieniem dla jezuitów w reformie szkolnictwa XVIII wieku? „Analecta” 2001, z. 2, s. 58-59. 
wyraźne zmiany. Miały one na celu dostosowanie repertuaru do nowych, oświeceniowych już tendencji. Dramaturgia jezuicka podlegała procesowi klasycyzacji. Zalecenia Ratio studiorum pozostawały, oczywiście, nadal ważne, ale to przede wszystkim praktyka sceniczna miała wpływ na kształt dramatów. Taki stan rzeczy był w mniejszym lub większym stopniu aprobowany przez przełożonych zakonu ${ }^{7}$.

Pierwsze symptomy owych reform można zaobserwować już u wcześniejszych dramaturgów jezuickich, m.in. u Wojciecha Bystrzonowskiego, Tomasza Baczyńskiego i Michała Wielowieyskiego. Rola tych autorów, zdaniem Jana Okonia, wiązała się z ,przygotowaniem podłoża" dla teatru w połowie XVIII wieku ${ }^{8}$. Twórczość dramaturgiczna Bielskiego odzwierciedlała proces zmian, jakie zachodziły w teatrze jezuickim w XVIII stuleciu, i stanowiła ich istotny przejaw.

Na modernizację dramatów jezuickich wpływ miało kilka czynników. Jednym z nich były niewątpliwie kontakty profesorów, w tym także Jana Bielskiego, z Józefem Andrzejem Załuskim. Szeroki krąg zainteresowań biskupa objął też teatr. Współtwórca słynnej biblioteki uważał, że poezja dramatyczna to istotny czynnik kultury literackiej. O bliskich kontaktach Bielskiego z Załuskim świadczą listy znajdujące się w zbiorach Biblioteki Narodowej. Jezuita wysyłał je jeszcze jako profesor kolegium w Rawie. Zachowana korespondencja dowodzi, że twórca Apoloniusza, Chrystusów rycerza tłumaczył, przepisywał i poprawiał na zlecenie biskupa dzieła literackie ${ }^{9}$. Przesłał również Załuskiemu w 1748 r. swoje dwie tragedie: Tytusa Japończyka oraz Zeyfadyna, króla Ormuzu (z przedmową, która nie mogła się ukazać z powodu zakonnej cenzury) ${ }^{10}$. Bielski wziął także udział w konkursie literackim z okazji inauguracji Biblioteki. W roku 1746 Załuscy ogłosili konkurs na napisanie po łacinie dzieła ,de utilitate insigni ex Bibliothecis publicis in scientias et artes prommanante [o wyjątkowej roli bibliotek publicznych w krzewieniu nauk i sztuk]" "11. Sam Załuski w utworze Biblioteka historyków, prawników, polityków i innych autorów polskich [...] określił Bielskiego mianem swojego przyjaciela oraz ,wielkiego krasomówcy” ${ }^{12}$. Według zaś Jana Daniela Janockiego, wieloletniego bliskiego współpracownika biskupa, polszczyzna autora Zeyfadyna, króla Ormuzu odznaczała się gładkością i polorem, a jego mowy

${ }^{7}$ P o p late k (op. cit., s. 11), charakteryzując okres od połowy w. XVIII, zauważa, że spotkały się wówczas dwie krzyżujące się tendencje. Profesorowie - kierownicy teatru - zmieniają repertuar za przykładem teatrów świeckich i dążą do uzyskania jak najdalej idących dyspens od przepisów Ratio studiorum. Przełożeni zaś stoją na ich straży i, jak stwierdza badacz: „hamują niezdrową gonitwę za nowością i sensacją, strzegą, by teatr nie odstąpił od wytkniętego mu celu i nie przynosił szkody normalnej pracy szkolnej". Zob. też KZ 13; KW 24. - B. J u d k o w i a k, Wzgardzony wielogłos. Kultura teatralna czasów saskich i jej tradycje. Poznań 2007, s. 11.

${ }^{8}$ J. O k oń, Autorzy tekstów dramatycznych w rękopisie 182 Biblioteki Jagiellońskiej. „Biuletyn Biblioteki Jagiellońskiej” 1971, s. 121-125.

${ }^{9}$ Korespondencja J. A. Zatuskiego rok 1745. T. 1. Bibl. Narodowa, rkps III 3245, k. 11-15. Zob. P 233-234. O związkach Załuskiego z jezuitami zob. też L. G r z e b i e ń, J. A. Załuski i jezuici. „Roczniki Teologiczno-Kanoniczne” 1994, z. 4.

${ }^{10}$ J. B i e ls k i: Tytus Japończyk. Poznań 1748; Zeyfadyn, król Ormuzu. Kalisz 1747. Zob. J u d k o w i a k, Wzgardzony wielogłos, s. 81-115.

${ }^{11}$ Oprócz Bielskiego swe prace przesłało także ośmiu innych zakonników. Nie zostały one jednak opublikowane, wbrew wcześniejszym zapewnieniom organizatorów. Zob. J. K o zło w s k i, Szkice o dziejach Biblioteki Załuskich. Wrocław 1986, s. 67-69.

${ }_{12}$ J. J. Z a ł u s k i, Biblioteka historyków, prawników, polityków i innych autorów polskich lub o Polsce piszacych. Kraków 1832, s. 64. 
nawiązywały do „okresu złotego wieku” ${ }^{13}$. Trzeba, oczywiście, zastrzec, że na zdanie Janockiego mógł oddziaływać sam Załuski, z którym bibliograf był przez wiele lat związany.

Na przemiany w dramaturgii jezuitów w Polsce wpływ miała również działalność konkurencyjnych teatrów szkolnych - pijarów i teatynów, wraz z ich nowoczesnym, europejskim repertuarem. W wielu pracach powtarza się opinia o niesamodzielności reformy jezuickiej oraz o jej „,wtórności” wobec propozycji Konarskiego. Dramaty jezuickie z tego okresu zyskiwały niekiedy określenie „kompromisowych", łączących to, co zaproponowali pijarzy, z tradycyjnymi elementami, które nie burzyły dotychczasowych zasad. Pisano o szablonowości sztuk jezuickich. Przeciwstawiano też nieprzejednany konserwatyzm jezuitów nowatorstwu pijarów, którzy wprowadzili do swoich sztuk role kobiece i tematykę miłosną ${ }^{14}$. Działalność konkurencyjnych zakonów na pewno nie pozostała bez wpływu na kształt dramaturgii jezuickiej w początkach XVIII wieku. Wszakże wystąpienia teatynów i Konarskiego stanowiły dodatkową, zewnętrzną podnietę i były tylko jednym z czynników zmian w szkolnictwie jezuickim. Ponieważ reformy zachodziły stopniowo (najpierw edukowano nową kadrę profesorów, następnie modyfikowano podręczniki, zdobywano środki materialne, a w końcu urządzano publiczne popisy), miały spokojniejszy przebieg niż program Konarskiego.

$\mathrm{Na}$ gruncie teatralnym przemiany były inicjatywą kolegialnych profesorów i wynikały z praktyki scenicznej. Konieczność zajęcia stanowiska wobec teatralnych poczynań pijarów i teatynów spowodowała jedynie, że na przełomie lat trzydziestych i czterdziestych XVIII w. owo współzawodnictwo nabrało dynamiki ${ }^{15}$. Odzwierciedleniem tego zjawiska jest chociażby zainicjowana przez Konarskiego dyskusja na temat miejsca postaci kobiecych w sztukach zakonnych (w przedmowie do przeróbki Ottona Corneille'a z 1744 r.). Swą propozycję zawarł Konarski w trzech krótkich zdaniach. Lapidarność formy nie umniejsza wcale przełomowego charakteru owej deklaracji ${ }^{16}$. Tak odważne wystąpienie wywołało gwałtowną reakcję ze strony Bielskiego. Jego odpowiedź (zamieszczona w przedmowie do tragedii Zeyfadyn, król Ormuzu) - broniąca jezuickiej tradycji - koresponduje ze współczesnymi dyskusjami europejskimi, które, zdaniem Judkowiak, zgadzały się

13 J. D. J a n o c k i, Polonia litterata nostri temporis. Wrocław 1750, s. 7-8.

14 Zob. M. S zyjk ow ski, Dzieje nowożytnej tragedii polskiej. Typ pseudoklasyczny (1661-1831). Kraków 1920, s. 72. - W. K w i a t k o w s k i, Teatr szkolny Kolegium Jezuickiego w Kaliszu. Kalisz 1936, s. 24. - Gra b ow s k i, op. cit., s. 18.- S. K a s z yń s k i, Teatr. W zb.: Dzieje Kalisza. Red. W. Rusiński. Poznań 1977, s. 271.

15 Zob. B e d n ar s k i, op. cit., s. 31-48, 54-57. - P 202. - KZ 10. - G r z e b i e ń, Czy Stanisław Konarski SP był natchnieniem dla jezuitów [...], s. 53, 59-61. - JP 134.

${ }^{16} \mathrm{O}$ powadze tego wystąpienia pisali liczni badacze - zob. literaturę zgromadzoną w bibliografii Dramat staropolski od początków do powstania sceny narodowej (t. 1: Teksty dramatyczne drukiem wydane do r. 1765. Red. nauk. A. Kawecka-Gryczowa. Oprac. zespół pod kierunkiem W. K o r o t a j a. Wrocław 1965, poz. 262). Z prac późniejszych zob. J. P a w ł o w i c z o w a, Teatr i krytyka. W zb.: Teatr Narodowy 1765-1794. Red. J. Kott. Warszawa 1967, s. 74. - W. K o zło ws k a, ,Otto” Corneille'a w adaptacji Konarskiego. „Zeszyty Naukowe Wydziału Humanistycznego Uniwersytetu Gdańskiego. Prace Historycznoliterackie” z. 8/9 (1985): Studia nad oświeceniem. R. D ą b r o w s k i, ,Otto” Stanistawa Konarskiego a „Otton” Pierre'a Corneille'a. ,Zeszyty Naukowe Uniwersytetu Jagiellońskiego. Prace Historycznoliterackie” z. 97/98 (2002/2003), s. 9. M. B rodn icki, Hermeneutyczny model pijarskiego teatru szkolnego w koncepcji Stanisława Konarskiego na przyktadzie tragedii „,Otto” Corneille'a. „Rocznik Gdański” z. 1/2 (2005), s. 145. 
z "horyzontem wysokich wymagań etycznych, w jakim obracał się teatr szkolny” (JT 35) ${ }^{17}$. Oba teksty miały charakter deklaratywny i odwzorowywały proces zwiększania się świadomości teatralnej ${ }^{18}$. Bielski wysuwa w swej przedmowie wiele argumentów przeciwko propozycjom pijara ${ }^{19}$. Ta mnogość racji sprawia, że jest ona nieporównywalnie dłuższa od uwag Konarskiego. Bielski swoje opinie wzbogaca treściami emocjonalnymi, dlatego jego wystąpienie jest pełne pasji i nieskrywanej niechęci wobec wypowiedzi poprzednika ${ }^{20}$. Jak spostrzegły Teresa Kostkiewiczowa i Elżbieta Sarnowska-Temeriusz: zasadę kompozycyjną przedmowy Bielskiego stanowi posługiwanie się ciągami enumerowanych argumentów przeplatanych pytaniami retorycznymi, które mają dowieść racji autora i zdeprecjonować tezy adwersarza ${ }^{21}$. W Przemowie do Czytelnika Bielski przywołuje bardzo wiele nazwisk osób, których autorytet i dokonania mają potwierdzić tezę o szkodliwości umieszczania na scenie szkolnej postaci kobiecych. Jezuita stara się w ten sposób zobiektywizować swój wywód. Za św. Janem Chryzostomem pyta o to, kim jest aktor, i wśród wielu godnych nagany wcieleń histriona wymienia kobietę ${ }^{22}$. Odwołuje się do filozofów i pisarzy antycznych (Platona, Kwintyliana, Cycerona, Arystotelesa, Seneki, Eurypidesa) i chrześcijańskich (św. Jana Chryzostoma, św. Augustyna). Przywołuje także twórców sobie współczesnych, zarówno dramatopisarzy zakonnych (m.in. francuskich jezuitów z paryskiego Collège Louis le Grand: Gabriela Le Jaya, Charles'a Poréego, Jeana Du Cerceau), jak też świeckich (Pierre'a Corneille'a, Woltera, Michaela Josepha Morei). Świadczy to niewątpliwie o rozległej erudycji Bielskiego i uaktualnionym zapleczu lekturowym jezuity. Podsumowując swoje wywody, Bielski wysuwa jeszcze inny, z ducha już oświeceniowy, argument. Przypomina fragment mowy Cellotiusa, w której francuski zakonnik wśród absolwentów jezuickich kolegiów wymienił mężnych żołnierzy, senatorów, sprawiedliwych sędziów, osoby wierne majestatowi i kochające ojczyznę $e^{23}$. Bielski przyczynę takiego stanu rzeczy upatruje w odpowiednim wy-

17 Zob. też JP 135.

${ }_{18}$ Zob. Pawłowiczowa, op. cit., s. 71.

19 Trzeba przypomnieć, że J. B i elski wystąpił dwukrotnie przeciwko S. Konarskiemu i pijarskiemu szkolnictwu w mowach inauguracyjnych z lat 1746-1747. Jezuita bronił w nich gramatyki Alwara i idei szkół publicznych (Pro institutione grammatica Emmanuelis Alvari [...] 〈Poznań 1746〉; Pro scholis publicis [...] oratio 〈Poznań 1747〉). Zob. też Z ał ę s k i, op. cit. - S. B e dn a r s k i, Bielski Jan. Hasło w: Polski stownik biograficzny. T. 2. Kraków 1936, s. 61. - Historia nauki polskiej. T. 6. Red. B. Suchodolski. Wrocław 1974, s. 39. - L. Grz e b i én, Bielski Jan. Hasło w: Encyklopedia katolicka. T. 2. Red. F. Gryglewicz, R. Łukaszyk, Z. Sułowski. Lublin 1985.

${ }^{20}$ W literaturze przedmiotu spotyka się wręcz określenia „ostry” i ,szydliwy” (Pisarze polskiego oświecenia. Red. T. Kostkiewiczowa, Z. Goliński. T. 1. Warszawa 1992, s. 20-21).

${ }^{21}$ E. S a rnow s k a-Te m e ri u s z, T. K os t k i e w i c z o w a, Krytyka literacka $w$ Polsce w XVI i XVII wieku oraz w epoce oświecenia. Wrocław 1990, s. 194.

${ }_{22}$ Bielski w przypisie lokalizuje cytat jako homilię 38 św. Jana Chryzostoma na Ewangelię św. Mateusza. Wydaje się jednak, że jezuita nie korzystał z oryginału pism Złotoustego Kaznodziei. Wyzyskał raczej zbiór o charakterze kompendium, w którym zebrano wypowiedzi przedstawicieli Kościoła na temat komedii - zob. Doctrina ss. Patrum de comoedia et spectaculis. W: A. d e B o u r b o n C o t i, Traité de la comédie et des spectacles, selon la tradition de l'Église tirée des Conciles et des Saints Pères. Paris 1667, s. 67.

${ }^{23}$ R. P. L. C e 11 o t i i Quondam in Academia Parisiensi Oratoris celeberrimi, Orationes Panegyricae: Nunc post varias in Gallia et Belgio factas impressiones bono et commodo Eloquentiae Studiosorum in Germania recusae. Paris 1607. 
chowaniu młodzieży, która unika niewieścich afektów. Przyznaje na koniec, że „zniewieściałe umysły do wysokich o Bogu, o ojczyźnie myśli niesposobne”"24.

Odnowiony teatr zarówno pijarów, jak i jezuitów zwrócił się ku repertuarowi francuskiemu ${ }^{25}$. Tłumaczono i parafrazowano ówczesnych tragików francuskich - Corneille'a, Racine'a, Woltera ${ }^{26}$. U jezuitów repertuar francuski był, oczywiście, wprowadzany stopniowo, najwcześniej w kolegiach warszawskim, wileńskim, poznańskim, lubelskim i kaliskim. Przewodnikami nowego nurtu stali się reformatorzy dramatu z paryskiego Collège Louis le Grand: Le Jay, Porée i Du Cerceau ${ }^{27}$. Francuscy jezuici zachowywali w tragediach zasady moralności chrześcijańskiej, realizowali klasycystyczny model tragedii regularnej oraz adaptowali świeckie komedie (np. Moliera) ${ }^{28}$. Le Jay w swoim podręczniku retoryki i poetyki Bibliotheca Rhetorum (1725) dostrzegł konieczność adaptacji teatru do współczesnych wymogów. Postulował on dostosowanie tematyki antycznej do potrzeb chrześcijańskiego widza. Według jezuity należało w dramatach unikać wątków miłosnych, a co za tym idzie, nie wprowadzać na scenę postaci kobiecych. Tematykę erotyczną powinny zastąpić inne, ,męskie” namiętności, np. żądza władzy, intrygi oraz spiski dworskie, działania bohaterskich męczenników i wyznawców ${ }^{29}$.

Podobnie uważał Porée. W mowie o teatrze, wygłoszonej 13 III 1733, wyrażał on znane już wcześniej przekonanie o wychowawczej funkcji teatru. Dla Poréego teatr to sztuka, która niesie prawdę o życiu i świecie, ,szkoła” przygotowująca umysł do cnoty. Ma ponadto przewagę nad historią i filozofią moralną, gdyż „,karmi się autentyczną prawdą" i „nie cieszy ich [tj. widzów] podniebienia i gardła byle czym" (KP 110) ${ }^{30}$. Jezuita przypisywał publiczności rolę aktywnego uczestnika spektaklu, pozwalał na głośne sprzeciwianie się, jeżeli sztuka nie ma odpowiednio wysokiego poziomu, którego zachowanie było obowiązkiem wobec ojczyzny i religii, realizacją powinności obywatelskich i chrześcijańskich. Dlatego rola publiczności nie ogranicza się wyłącznie do wizualnego odbioru spektaklu. Widzowie stają się jego odpowiedzialnymi współtwórcami (KP 109-110). Warto wspomnieć, że traktat Poréego Oratio de theatro opublikowano w Poznaniu już

${ }^{24}$ J. B i e $1 \mathrm{~s} \mathrm{k} \mathrm{i,} \mathrm{Przemowa} \mathrm{do} \mathrm{Czytelnika.} \mathrm{W:} \mathrm{Zeyfadyn,} \mathrm{król} \mathrm{Ormuzu,} \mathrm{k.} \mathrm{b}{ }_{2 \text {. }}$.

${ }_{25}$ Dla P i etras zki (P 235-236) oznaki nowej dramaturgii jezuickiej uwidocznily się już pod koniec XVII wieku. Źródeł owych przemian dopatrywał się badacz właśnie we wpływie klasycystycznego teatru francuskiego.

26 Tragedie Corneille'a zyskały na popularności w kolegiach jezuitów dzięki tematyce (politycznej i martyrologicznej) oraz formie (w scenach dramatycznych istotne miejsce zajmowała dysputa). Sam Corneille chętnie sięgał do historyków jezuickich - Suriusa i Baroniusa, gdyż uważał, że tragik musi opierać się na prawdzie historycznej. Istotne miejsce w dramatach francuskiego autora zajmowały też kwestie obywatelskie (G r a b o w s k i, op. cit., s. 13). Sztukę Woltera parafrazował W. M o k r o n o w s k i (Śmierć Cezara. Warszawa 1755), Racine zaś zdobył popularność zwłaszcza na scenie pijarskiej (zob. B. S o s i e ń, wstęp w: J. B. R a c i n e, Andromacha.-Berenika. -Fedra. Przeł. M. Wroncka, K. Brończyk, A. Międzyrzecki. Oprac. B. Sosień. Wrocław 1997, s. LXXXII. BN II 242).

${ }_{27}$ Zob. Kadulsk a, Miejsce Franciszka Bohomolca $w$ osiagnięciach teatru jezuickiego, s. $113-114$.

${ }_{28}$ Zob. M. K 1 i m o w i c z, Oświecenie. Wyd. 8. Warszawa 2002, s. 78-79.

29 Zob. S. P i g o ń, Z dziejów dawnego teatru szkolnego. „Pamiętnik Literacki” 1952, z. 1/2, s. 291-293. - KZ 8 .

${ }^{30} \mathrm{Ch}$. P o r é e, Oratio V: Theatrum sit ne, vel esse possit schola informandis moribus idonea. W: Orationes [...]. Moguntiae-Francofurtii ad Maenum 1756, s. 136 n. Zob. JT 37-38. 
w 1748 roku. Dzieło to cieszyło się w XVIII w. dużą popularnością. Podobną poczytność zyskał także podręcznik Le Jaya, w którym obok prawideł i przykładów znalazły się również dramaty jezuity (w Liber dramaticus). Bibliotheca Rhetorum była wykorzystywana w polskich kolegiach od połowy XVIII aż do XIX stulecia (P 202) ${ }^{31}$. Poglądy francuskich jezuitów przyczyniły się niewątpliwie do upowszechnienia klasycystycznego modelu teatru wśród profesorów polskich kolegiów. Zaczęto również parafrazować utwory dramaturgów znad Sekwany ${ }^{32}$. Wzory francuskie zostały jednak przystosowane do polskich realiów. Przykładem może być znacznie szersze niż $\mathrm{w}$ dramatach francuskich posługiwanie się kostiumem antycznym. Wynikało to, zdaniem Pietraszki, z sarmackiego obyczaju i upodobań szlacheckiego odbiorcy (P 196; zob. też KZ 14).

W twórczości Bielskiego nie ma, co prawda, bezpośrednich zapożyczeń z dzieł francuskiego dramatopisarza, ale nazwisko Le Jaya oraz kilku innych francuskich jezuitów z paryskiego Collège Louis le Grand (m.in. Poréego i Du Cerceau) pojawia się w Przemowie do Czytelnika z tragedii Zeyfadyn, król Ormuzu. Treść utworów francuskich dramatopisarzy dostosowuje autor do własnej tezy. W pozostałych tragediach źródłami Bielskiego są przede wszystkim popularne dzieła o charakterze historycznym, syntezy, zbiory budujące i umoralniające. A więc obok Annales ecclesiastici Cezarego Baroniusza (m.in. w thumaczeniu Piotra Skargi) i ich kontynuacji (autorstwa Odorica Rinaldiego) ${ }^{33}$ wykorzystał Bielski też dzieła Tobiasa Lohnera Instructissima bibliotheca manualis concionatoria (Dillingen 1681), Josepha Jouvancy'ego Historia Societatis Iesu (Romae 1615-1659) oraz „kronikę” Philippusa Brietiusa, Annales Mundi sive Chronicon Universale (Viennae 1727) ${ }^{34}$. Pomysły czerpał Bielski także z dzieł o charakterze przewodników duchowych oraz ze zbiorów podających budujące przykłady autorstwa Georgiusa Stengeliusa, Laurentiusa Beyerlincka czy też Antoniego Świrczyńskiego ${ }^{35}$. Podstawą jego tragedii były również teksty o charakterze kompendiów, np. Pierre’a Du Jarrica,

${ }^{31}$ P i g o ń (op. cit., s. 295, przypis 13) przedstawił zabawną reakcję Filipa Platera, wizytującego szkołę w Winnicy, na słabe postępy uczniów w zakresie wymowy i poezji. Gdy nauczyciel odpowiedział wizytatorowi, że wykłada według Le Jaya, ten oznajmił: „Widać to, bo i uczniowie, i pan leżycie".

32 Wśród zaadaptowanych na scenę polską utworów G. L e J a y a wymienić można tragedię Abdalomin J. P uttka mera (Sandomierz 1754), komedię F. B o h o m olc a Filozof panujący (Warszawa 1756). Dramaty Ch. P oré e go parafrazowali m.in. A. Przera dzki (Maurycjusz, państw wschodnich cesarz. Tragedia 〈Poznań 1754〉) oraz F. B o h o m o l e c (Ojciec nieroztropny 〈Warszawa 1755〉; Figlacki, kawaler z księżyca 〈Warszawa 1757〉). Ten ostatni przerobił również sztukę J.-A. D u C e r c e a u (Kłopoty panów 〈Warszawa 1760)).

${ }_{33}$ P. S k a rg a, Roczne dzieje kościelne. Kraków 1603. - O. R in a ld i (R a y n a ld i), Annales ecclesiastici. Romae 1646-1677.

${ }^{34} \mathrm{Ph}$. Brietius był zresztą autorem zalecanym przez Juwencjusza przy nauczaniu nowej, zreformowanej geografii. Paryski jezuita w traktacie De ratione discendi et docendi zalecał, by w szkołach uczniowie analizowali mapy i tablice geograficzne za trzytomowym podręcznikiem Paralela geographiae veteris et novae (zob. K. P u c h o w s k i, Jezuickie kolegia szlacheckie Rzeczypospolitej Obojga Narodów. Studium z dziejów edukacji elit. Gdańsk 2007, s. 119).

${ }^{35}$ G. S t e n g e li u s, Exemplorum libri tres. T. 2. Ingolstadii 1650. - L. B e ye r 1 in ck, Magnum theatrum vitae humane [...]. T. 3. Lugduni 1665. - A. Ś w i r c z ý s k i, Droga do zbawienia przez rozumne rozporzadzenie życia doczesnego wedle oświecenia i powotania Boskiego wyprostowana [...]. Wyd. 2. Lublin 1764. 
Histoire des choses plus mémorables advenues tant ez Indes Orientales [...] (Bordeaux 1608-1610) ${ }^{36}$.

Nowa tragedia jezuicka zwróciła się w stronę polskiej tradycji literackiej i kulturowej. Obok dzieł Jana Kochanowskiego (których edycję po długim okresie zapomnienia przygotował w 1767 r. Franciszek Bohomolec $\left\langle\right.$ P 200-201, 243 ${ }^{37}$ ) stawiane były za wzór utwory m.in. Wacława Potockiego, Samuela Twardowskiego czy Piotra Kochanowskiego ${ }^{38}$. Bielski w przedmowie do swojego Ćwiczenia krasomówsko-prawnego pisał, iż „podnietę” do skomponowania zbioru znalazł w przykładach dawnych mów polskich, zamieszczonych w pismach m.in. Łukasza Górnickiego, Jana Stefana Pisarskiego, Józefa Andrzeja Załuskiego, Krzysztofa Stanisława Zawiszy oraz w Swadzie polskiej Jana Danejkowicza Ostrowskiego. Jezuita doceniał kompozycję (,,kształt”) rodzimych oracji, ich walory estetyczne i retoryczne. Zdaniem Bielskiego, przypominały one mowy Cycerona (,z takim w nie przeniesieniem wdzięków, ozdób, mocy i dostatku cyceronowego, iżbym rozumiał, że je u sądowego stołu przestrojony w krój polski mówił tenże Cycero" ${ }^{39}$ ). W tragediach jezuity można również dostrzec nawiązania do polskiej tradycji literackiej. Owe nieliczne inspiracje uwidaczniają się najwyraźniej na płaszczyźnie inwencyjnej. Obok źródeł obcych znalazły się także rodzime: Roczne dzieje kościelne w wersji Skargi, podręcznik Świrczyńskiego czy też kompendium Władysława Aleksandra Łubieńskiego, Świat we wszystkich swoich częściach [...] okryślony ${ }^{40}$. Niektóre rozwiązania struktury dramaturgicznej zastosowane przez Bielskiego przypominają te, które (choć znane tragediom antycznym) pojawiły się już w Odprawie postów greckich Jana Kochanowskiego. We wszystkich dramatach jezuity występuje zatem stychomytia oraz identyfikowanie jednych postaci przez inne (czasem wzbogacone dodatkowymi informacjami: o zachowaniu się wchodzącego na scenę bohatera czy też o stosunku osoby wypowiadającej słowa do nazywanej persony).

${ }^{36}$ Kompendia w staropolszczyźnie były niezwykle popularne. Sumowały dotychczasowy stan wiedzy z różnych dziedzin. Ich rola polegała też jednak na inspirowaniu kolejnych nowych jakościowo (i gatunkowo) utworów. Zob. J. O k o ń, Kompendium - czy tylko wiedzy? Wstęp do typologii gatunku. W zb.: Staropolskie kompendia wiedzy. Red. I. M. Dacka-Górzyńska, J. Partyka. Warszawa 2009, s. 9-10.

37 Zob. też R. Gr z eś k ow i a k, Jan Kochanowski - klasyk i klasycysta. Rzecz czarnoleska jako rzecz pospolita poetów początku baroku. W zb.: Klasycyzm. Estetyka, doktryna literacka, antropologia. Red. K. Meller. Warszawa 2009, s. 184-185. W tym samym tomie o Kochanowskim jako o ,klasyku wysokiej klasy” pisała też E. B u s z e w i c z (Klasycyzm w liryce staropolskiej. W zb.: jw.).

${ }^{38}$ A. Przera d z k i (Dedykacja. W: Maurycjusz, państw wschodnich cesarz. Cyt. za: KZ 18-19) określił S. Twardowskiego mianem, „wielkiej polskiego świata poetów ozdoby”, P. Kochanowskiego zaś rymotwórcą „,nie mniejszej sławy”.

39 J. B i e ls k i, Przemowa do Czytelnika. W: Ćwiczenia krasomówsko-prawnego [...] ksiega I. Poznań 1757, k. a. Według Ka d u $1 \mathrm{~s} \mathrm{ki} \mathrm{ej} \mathrm{(KZ} \mathrm{17-19)} \mathrm{jezuici} \mathrm{poprzez} \mathrm{nobilitację} \mathrm{rodzimych} \mathrm{au-}$ torów „przerzucili pomost, którym poszło potem oświecenie”. Zob. też P. B u chwald-P elc o w a, ,Stare” $i$,nowe” w czasach saskich. W: Historia literatury i historia ksiażki. Studia nad ksiażka i literatura od średniowiecza po wiek XVIII. Kraków 2005, s. 524.

${ }_{40}$ Dzieło W. A. Łu u i eń s k i e g o Świat we wszystkich swoich częściach większych i mniejszych [...] okryślony (t. 1. Wrocław 1740) pojawiło się jako przypis źródłowy w tragedii o Zeyfadynie przy okazji omawiania zwyczaju spożywania poświęconego cukru towarzyszącego królom perskim podczas intronizacji. 
Postawa szacunku wobec dokonań polskich twórców przyczyniła się do nobilitacji polszczyzny w zreformowanych tragediach jezuickich. Wbrew zaleceniom Ratio studiorum, lecz przy milczącej zgodzie przełożonych, liczne dramaty pisane były po polsku. Język narodowy znalazł swe miejsce także w sztukach oficjalnych, tzn. nie związanych z życiem szkolnym czy uroczystościami religijnymi ${ }^{41}$. Wymowna jest wypowiedź Jaworskiego, który we wspomnianej Przestrodze do Czytelnika tłumaczy się z własnej niedoskonałości, „słów braku [...]”, i dodaje:

w słowach swoich szczeropolskich przyuboższy już został język nasz ojczysty i że prócz pomienionego poety [tj. Jana Kochanowskiego] mało co widzieć możemy wydanych z druku polszczyzną tragedii, których by naśladować rzecz godna była, a zatem prawie pierwszy lód łamać nam przyszło ${ }^{42}$.

Bielski, co prawda, nie wzbogacił swoich utworów dramatycznych o treści programowe dotyczące języka (wyjątek stanowi wspomniany już zbiór pisanych na użytek dydaktyczny ,sądów prawnych”, tzn. Ćwiczenie krasomówsko-prawne). Jednak jego dzieła odzwierciedlają wyraźnie nowy sposób myślenia o tragedii w służbie dydaktyki szkolnej. Większość swoich dramatów napisał jezuita po polsku, z myślą o doskonaleniu języka ojczystego przez młodzież szkolną. Wyjątek stanowi najwcześniejszy spośród utworów Bielskiego - Vandamorillus, tragoedia, wydany i wystawiony w marcu 1747 w Kaliszu. Dramat ten, którego osnową był epizod z historii Anglii, napisany został po łacinie. Ukazywał dzieje niezłomnego rycerza - Vandamorillusa, który wyzbył się żądzy zemsty na mordercach swych rodziców, lecz na skutek pomówienia król Ryszard go wygnał. Dopiero interwencja sił Boskich oraz moc modlitwy sprawiły, że niewinny bohater odzyskał łaskę monarchy ${ }^{43}$. W dorobku Bielskiego znajduje się, co prawda, jeszcze jeden utwór dramatyczny uwieczniony w języku łacińskim. Sztuka Vocatio Divina (Poznań 1751), zapisana bezpośrednio po tragedii o Konstantynie Wielkim, nie jest wszakże tragedią. Została ona określona w rękopisie jako „actio oratoria”. To krótka, trzyaktowa sztuka, oparta na epizodzie z Wyznań św. Augustyna, a zaczerpnięta przez Bielskiego bezpośrednio z książki Antoniego Świrczyńskiego Droga do Zbawienia. O ile utwór o Konstantynie Wielkim zawiera rozbudowaną tytulaturę wraz z określeniem wykonawców, miejsca i czasu wystawienia, o tyle Vocatio Divina pozbawiona została tych informacji. Możliwe, iż był to tekst napisany na potrzeby zajęć dydaktycznych, bez przeznaczenia do odegrania publicznego. Łacińska deklamacja stanowiła zatem praktyczne ćwiczenie dla uczniów. Natomiast dramaty, które w tytule zawierały określenie gatunkowe, tworzone były po polsku, poczynając od Zeyfadyna, króla Ormuzu, a kończąc na Aleksym, cesarzu wschodnim ${ }^{44}$.

Świadome posługiwanie się w teatrze szkolnym polszczyzną wynikało zapew-

${ }^{41}$ Zob. KZ 22-24. - JP 133. Jak stwierdziła K o s t k i e w i c z o w a (Klasycyzm, sentymentalizm, rokoko, s. 22 n.), renesans był jednym z ważniejszych czynników kształtujących polski klasycyzm.

$42 \mathrm{~J}$ a w or s k i, op. cit., s. 135.

${ }^{43}$ Realia historyczne nie odgrywają w sztuce istotnej roli. Fabuła tragedii opiera się na epizodzie zaczęrpniętym z żywotu św. Jana Gwalberta, mnicha benedyktyńskiego (X-XI w.). Motyw ten podjął też w w. XVII jezuicki autor sztuki Memorabile de Jesu crucifixo meritum (Wilno 1679). Zob. J. O k o ń, Dramat i teatr szkolny. Sceny jezuickie XVII wieku. Wrocław 1970, s. 185. - Dramat staropolski od początków do powstania sceny narodowej. Bibliografia. T. 2, cz. 1. Oprac. W. K orotaj, J. S z w e d o w s k a, M. S z y m ań s k a. Wrocław 1976, poz. 514.

${ }_{44}$ Wyjątkiem jest początkowy fragment tragedii Konstantyn Wielki, pierwszy chrześcijański 
ne z wysokiej rangi, jaką Bielski przypisał sztuce wymowy. Dał temu wyraz we wstępie do Ćwiczenia krasomówsko-prawnego, gdy stwierdzał, że oratorstwo to rodzaj „,bezgrotnego oręża”, który „poleruje” wymowę i dowcip, lecz jest też podporą dla ojczyzny ${ }^{45}$. Doskonalenie wymowy nie tylko więc stawało się celem już praktycznym (dla przyszłego oratora sejmikowego), ale urastało do rangi powinności obywatelskiej.

Polszczyzna Bielskiego jest zrozumiała. Jezuita unika niepotrzebnej ozdobności stylu, ostrożnie wykorzystuje środki artystyczne. Najczęściej posługuje się przerzutnią oraz inwersją ${ }^{46}$. Jego dramaty reprezentują nowy sposób pisania, czerpiący nie tyle z estetyki barokowej, ile raczej z tradycji klasycystycznej (np. obszerne monologi-tyrady, które nawiązywały do tradycji antyku ${ }^{47}$ ). Trzeba pamiętać, że pierwsze sygnały występowania przeciwko ,zepsutej wymowie” pojawiły się u jezuitów polskich już w poetyce z r. 1692, a w latach trzydziestych XVIII w. przybrały na sile ${ }^{48}$. W oratorstwie ważna stawała się nie - jak dotychczas - uniezwyklona, a przez to zawiła forma. Raczej ceniono jasność myślenia i dowodzenia, rzeczowość argumentacji oraz wywód logiczny. Takie cechy wzorcowej oracji wymienił Jaworski w trzech mowach inauguracyjnych $(1746,1751,1758)$. Jezuita ten zalecał naśladowanie klasycznej łaciny Cycerona, potępiał zaś nadmierną ozdobność, która kłóciła się z prawdą, że „słowo jest wyrazem myśli”, a „wymowa jest sztuką dobrego mówienia" ${ }^{49}$. Podobne zdanie wypowiedział też Bielski w przedmowie do Ćwiczenia krasomówsko-prawnego.

Nowe cele postawione przed teatrem jezuickim wymuszały przeobrażenia w dotychczasowym kształcie dramatów szkolnych. Reformy wynikały z chęci unowocześnienia teatru oraz z konieczności sprostania wymaganiom publiczności, nierzadko obeznanej z klasycystycznym, europejskim repertuarem. Chodziło także o to, aby uatrakcyjnić dawne formy wyrazu scenicznego (KZ 8). Jedną ze zmian, jakie zaszły pod wpływem wzorów francuskich, była nobilitacja prozy oraz wiersza białego w tragediach. Formą bezrymowego 13-zgłoskowca posłużył się Jawor-

cesarz. Tragedia (Poznań 1751), w którym pogańscy kapłani wyśpiewują łacińską pieśń skierowaną do Jowisza.

${ }^{45} \mathrm{~B}$ i e ls k i, Ćwiczenia krasomówsko-prawnego [...], k. a, a $\mathrm{a}_{2}$.

${ }^{46}$ Zabiegi te dobrze ilustruje fragment tragedii J. Bielskie g o Apoloniusz, Chrystusów rycerz. Tragedia [...] (Poznań 1755, s. 14):

SABINIUSZ

[...] na przędzą

Syna życia nie hartuj nożyc Parko; skrycie

Mnie przedłużysz, przedłużysz synowi gdy życie.

Jego życia, ojcowska jest życia osnowa,

Ojciec zginie, gdy ojca, syn zginie, połowa.

47 Zob. J. O k o ń, O aktorach $i$ sztuce aktorskiej w staropolskim teatrze szkolnym jezuitów. W: Na scenach jezuickich w dawnej Polsce (rodzimość i europejskość). Warszawa 2006, s. 207.

${ }^{48} \mathrm{G}$ r z e b i én (Czy Stanisław Konarski SP byt natchnieniem dla jezuitów w reformie szkolnictwa XVIII wieku?, s. 55-56) zbija rzekome różnice między retoryką jezuicką a propozycją Konarskiego. Według autora obie były ,jedną i tą samą retoryką humanistyczną”. Ferment, jaki zaczął się u jezuitów pod koniec w. XVII, dowodził, że w kolegiach następowała zmiana poglądów. Badacz konkluduje: „wystąpienie Konarskiego było krokiem, dla którego warunki i atmosfera wśród warstwy intelektualnie postępowej były już w dużym stopniu przygotowane".

${ }_{49} \mathrm{~B}$ e d n a r s k i, Upadek $i$ odrodzenie szkót jezuickich $w$ Polsce, s. 220-222. Zob. też P uc h o w s k i, Jezuickie kolegia szlacheckie Rzeczypospolitej Obojga Narodów, s. 261. 
ski w tragedii Jonatas. Wyjaśnił on w Przestrodze do Czytelnika, że rymowane wypowiedzi zdają się „ujmować przyrodzonej osobom tragicznym powagi” ${ }^{50}$. Przywołał również autorytet Jana Kochanowskiego, który w Odprawie postów greckich zastosował wiersz biały „Z tej też samej zda [...] się przyczyny [...]" ${ }^{51}$. Natomiast prozatorską formę wypowiedzi artystycznej wybrał Jan Puttkamer w tragedii Abdalomin. Drama [...]. W przedmowie Do Czytelnika thumaczył, że polskie tragedie „wierszem ściśnione” są niezrozumiałe, a odbiorca nie odczuwa „upodobania”, tylko „tęsknicę”. Ten stan wynika, zdaniem dramaturga, z „nieprzyrodzonego i niepolskiego polskich słów przekładania, pomotania, oddalenia, zawikłania [...]" (cyt. za: KZ 25). Swe tragedie wierszem bezrymowym pisali również Wojciech Męciński (Regulus. Tragedia 〈Lublin 1753〉) oraz Antoni Przeradzki (Maurycjusz). Zapewne podobne pobudki przyświecały także Bielskiemu, który wszystkie swoje polskie tragedie napisał wierszem białym, łaciński zaś dramat Vandamorillus i dialog Vocatio Divina - prozą. Rezygnacja z wiersza, rymów oraz stałego położenia średniówki zbliżała wypowiedź do naturalnego toku mowy (KZ $25)^{52}$. W niektórych tragediach Bielski zamieścił, co prawda, niewielkie fragmenty rymowane. Różniły się one w zależności od miejsca wystąpienia. Jezuita wykorzystał rym w wypowiedziach o charakterze sentencjonalnym i moralizatorskim. Obejmowały one najczęściej dwa wersy. Z perspektywy rozwoju fabuły były zbędne - nie posuwały akcji naprzód. Przyciągały natomiast uwagę słuchaczy przyzwyczajonych do wypowiedzi prozą. Rym służył zatem zaakcentowaniu i uwypukleniu danej myśli:

\section{SEBAST}

Próżna groźba, sam często, królu, zdradę knuje,

Kto cudzą w podejrzenie niewinność wprawuje.

$[\ldots \ldots \ldots \ldots \ldots \ldots \ldots \ldots$

ZEYFADYN

[...] królem Cnota czyni

Nie siła; nie ukryją tego twierdze, wały

Przed prędką zemstą, komu do tronu usłały

Zbrodnie drogę $e^{53}$.

Rym powtarzał się regularnie w wypowiedziach kończących dany akt (wyjątek stanowi wczesna tragedia o Zeyfadynie, w której wierszowane fragmenty pojawiały się częściej w finale poszczególnych scen). Obejmowały one od 2 do 6 wersów i miały zwykle charakter moralizatorski. Owe rymowane wersy dzięki uogólnionym sformułowaniom i przenośniom poetyckim mogły odgrywać rolę samodzielnych treściowo, np.:

${ }^{50} \mathrm{~J}$ a w or s k i, op. cit., s. 135.

${ }^{51}$ Ibidem. Według K a d u 1 s ki e j (KZ 17) deklaracje autorów odzwierciedlały ich świadomość twórczą, uzasadniały postawę oraz propagowały nową teorię dramatu. Do ważniejszych wstępów badaczka zalicza te, które poprzedzają Zeyfadyna, króla Ormuzu i Ćwiczenie krasomówsko-prawne [...] Bielskiego, Komedie konwiktowe Bohomolca, Śmierć Cezara Mokronowskiego, Timoklę Pruszyńskiego, tragedię Przeradzkiego o Maurycjuszu, Abdalomina Puttkamera oraz przedmowę w anonimowej sztuce Arlekin, dziki Amerykanin. Istotna, zdaniem autorki, jest też Rozmowa o języku polskim Bohomolca.

${ }_{52}$ Zob. też JT 37; J u d k o w i a k, Wzgardzony wielogłos, s. 115.

${ }^{53}$ B i e ls k i, Zeyfadyn, król Ormuzu, s. 9, 20. 
MELEAND

$[\ldots \ldots \ldots \ldots \ldots \ldots \ldots \ldots \ldots$

Że miłość ogniem, wierzę: Patrz, co nie dasz wiary:

Miłości, trosków burza, rozżarza pożary ${ }^{54}$.

ARTEMI

Sprawiedliwości Boska, ty sprawiasz, że zdrada

Na głowę często samych obłudników spada,

I kto, jak mówią, dołki pod innymi knuje,

Chcąc innych pogrześć, częściej grób sobie gotuje ${ }^{55}$.

Niekiedy owe rymowane zakończenia aktów odnosiły się bezpośrednio do fabuły lub sytuacji (psychofizycznej) bohaterów. Postaci ujawniały swoje plany ${ }^{56}$ czy też emocje i uczucia. Np. gdy w tragedii Apoloniusz, Chrystusów rycerz zostaje zdemaskowany zdrajca Lucil, to wypowiada on prawdy na temat zmienności losu i nieopłacalności prowadzenia życia pozbawionego cnoty:

[...] ze mnie świecie bierz teraz nie lada

Przykład, głupia odbiera jaki profit zdrada ${ }^{57}$.

Rym pełnił w tej sytuacji funkcję delimitacyjną. Określał granicę między poszczególnymi aktami. W przypadku sztuk zawierających intermedia, owa granica była dość wyraźna. Wydaje się, że właśnie dlatego w tragedii Tytus Japończyk pojawiły się (dość przypadkowe) rymowane zakończenie i początek w dwóch następujących po sobie scenach (5 i $6 \mathrm{z}$ aktu III). W tragediach późniejszych, w których jezuita zrezygnował z intersceniów (np. Aleksy, cesarz wschodni), rym występował już wyłącznie w zakończeniach aktów.

Bielski porzucał nierymowany tok mowy również wtedy, gdy bohaterowie relacjonowali słowa innych. W dramacie Zeyfadyn, król Ormuzu zamieścił obszerną wypowiedź Sebasta, w której ten wierny tytułowemu królewiczowi dostojnik opisal, jak doszło do zgładzenia tyrana przez wodza Machometa (!) ${ }^{58}$. Warto zauważyć, że Bielski dość niekonsekwentnie stosował rym we fragmentach o charakterze relacji. Części te sprawiają czasem wrażenie przypadkowych. Gdy w tragedii Tytus Japończyk władca Bungu, Moryndor, przytacza słowa głównego bohatera, to miesza dwa porządki prozodyjne. Przytoczona wypowiedź Tytusa, rymowana tylko w połowie, została wyodrębniona w druku kursywą:

Czyliż przed sąd pozwałem Tyta? Dobrowolnie

Sam, wiecie, staną: miecze, haki, dzidy, groty,

${ }^{54}$ B i e 1 s k i, Tytus Japończyk, s. 23. Takie „ogniste” obrazowanie oddające siłę uczuć synowskich, z jednoczesnym zastosowaniem iście barokowego konceptu, pojawiło się też w zakończeniu aktu III tragedii Aleksy, cesarz wschodni. Tytułowy bohater wyznał:

Ach, jaka w sercu trwoga, jakie pomieszanie,

Przyczyny chcesz? Tę trwogę ojca poważanie,

Ojca miłość sprawuje. Serce w żalach, brodzi

W łzach oko - któż uwierzy? Ogień wodę rodzi.

${ }^{55}$ B i e $1 \mathrm{~s} \mathrm{k} \mathrm{i,} \mathrm{Konstantyn} \mathrm{Wielki,} \mathrm{pierwszy} \mathrm{chrześcijański} \mathrm{cesarz,} \mathrm{akt} \mathrm{III,} \mathrm{sc.} 12$.

${ }^{56}$ Przykładowo - w zakończeniu aktu III sztuki Tytus Japończyk (s. 34) Farada, przeciwnik prawowitego władcy, obiecuje zamordować króla.

57 B i e l s k i, Apoloniusz, Chrystusów rycerz, s. 35.

${ }^{58}$ B i e l s k i, Zeyfadyn, król Ormuzu, s. 5-8. 
Jeśli co dawnych jeszcze zastug pamięć każe,

Królu - woła - wywieraj. Laska dla mnie będzie

Największa, we krwi głowa, gdy złożona siędzie ${ }^{59}$.

W pewnych tragediach rym występował we fragmentach odrębnych gatunkowo, które miały charakter całości. W Zeyfadynie, królu Ormuzu widzimy więc wierszowane epitafium, tragedię Konstantyn Wielki otwierała łacińska pieśn tańczących wokół ognia kapłanów pogańskich, akt II zaś kończyła modlitwa, a w dramacie Niewinność zwycięża potwarzy ${ }^{60}$ znalazły się dwa wierszowane listy.

W zreformowanym szkolnictwie jezuickim pojawiło się też zagadnienie powinności obywatela wobec państwa. Dla twórców programu klasycystycznego istotne stawały się nie tyle rozważania o naturze ludzkiej, ile raczej pokazanie miejsca i zachowań ludzi w określonej społeczności. Wychwalano więc postawy i pobudki patriotyczne ${ }^{61}$. Zmiana poruszanej problematyki znalazła wyraz także w teatrze ${ }^{62}$. Również Bielski w swoich tragediach kładł nacisk na kwestie obywatelskie. Już w dramacie Zeyfadyn, król Ormuzu podjął zagadnienie powinności podwładnych względem prawowitego władcy oraz obowiązków panującego wobec poddanych. Zmiany, jakich dokonał Bielski w stosunku do podstawy źródłowej, czyli fragmentu drugiej księgi Exemplorum libri tres Stengeliusa ${ }^{63}$, miały na celu zaakcentowanie właśnie kwestii obywatelskich. W ujęciu niemieckiego jezuity wydarzenia z historii Ormuzu unaoczniały prawdę o zgubnym działaniu zazdrości i rywalizacji, które prowadzą do zbrodni. Tekst Stengeliusa ma charakter moralizatorski i dydaktyczny. Autor skupia się na opisaniu upadku Soldana - mordercy rodziców i braci. W księdze ważną funkcję pełnią liczne dygresje umoralniające oraz cytaty z innych autorów, które potwierdzają prawdę o diabelskiej naturze zazdrości. Głównymi bohaterami Stengeliusa stają się tyran Soldanus i wódz Machomet (!). Wojskowy stanowi uosobienie wielkości, zacności, nieulegania żądzy władzy. To oponent tyrana i jego zaprzeczenie. Natomiast młody książę Zeyfadyn jest, w ujęciu Stengeliusa, postacią drugoplanową, wręcz marionetkową. W powszechnej opinii uchodzi za człowieka szalonego, nie umiejącego dowodzić państwem. Tylko jeden raz wydaje on okrzyk rozpaczy na wieść o śmierci najbliższych, a następnie nie jest już bohaterem aktywnym. To inni decydują o jego losie.

Bielski w swojej tragedii rozłożył akcenty nieco odmiennie. W postaci hetmana Machometa (!), który zdobył powszechny poklask i uznanie ludzi, ale odrzucił tron Ormuzu i oddał go młodemu księciu, uobecniał jezuita wszelkie cnoty obywatela. Nie zajmował go zupełnie dominujący u Stengeliusa problem diabelskiej natury zazdrości. Zeyfadynowi u Bielskiego towarzyszy uczucie zawiści. Wywo-

${ }_{59}$ B i e 1 s k i, Tytus Japończyk, s. 30.

${ }^{60}$ J. B i e l s k i, Niewinność zwycięża potwarzy, czyli Leo VI cesarz. Tragedia. Poznań 1753. Bibl. Uniwersytetu Wileńskiego, rkps IV 11651/4.

${ }^{61}$ Zob. Ko s t k i e w i c z ow a, Klasycyzm, sentymentalizm, rokoko, s. 27.

${ }^{62}$ Warto przywołać tu słowa J. P e l c a (Klasycyzm w baroku - wprowadzenie do dyskusji. „Barok” 2000, nr 2, s. 22), dla którego „nowy klasycyzm” w zreformowanych teatrach szkolnych wyrażał się w tematyce patriotycznej. Wcześniej o wątkach patriotycznych w sztukach jezuickich oraz o „wyrabianiu myśli politycznej i moralnej społeczeństwa” pisał też L e w a ń s k i (op. cit., s. 8-9), choć w innym miejscu dodal, że przemiany owe wynikały z „obrony [...] stanu posiadania” (s. 11).

${ }^{63} \mathrm{~S}$ t e n ge li u s, op. cit. (chodzi o rozdz. 4: Invidiae et aemulationis crimen quousque se extendat? In regis filio parricida demonstrator). 
łuje je tryumf Machometa (!) (u Stengeliusa zamknięty raptem w czterech zdaniach). Zeyfadyn okazuje się intrygantem, którego decyzja o zabiciu wiernego hetmana staje się siła sprawcza, pociąga kolejne zdarzenia i powoduje zawikłania akcji. Młody książę to u Bielskiego postać aktywna, która przeżywa chwile radości i rozpaczy oraz targana jest emocjami. Ostatecznie ujawnia swe niegodne zachowanie, chroni przyjaciela przed zgubą i wyznaje winy. Tragedia Bielskiego pokazuje zatem młodzieńca, który dorasta do roli łaskawego monarchy. Przyznanie się do winy, wyrażenie skruchy i gotowość poniesienia kary są dowodem na to, że Zeyfadyn dojrzał do objęcia tronu. Ów proces zdobywania „,monarszej świadomości" stanowi ważny element tragedii Bielskiego.

O powinnościach poddanych wobec władcy mowa była też w kolejnej tragedii Bielskiego, Konstantyn Wielki. Jezuita oparł swój dramat na fragmencie Rocznych dziejów kościelnych Piotra Skargi. Źródłem intrygi uczynił cudowne uzdrowienie cesarza z trądu dzięki sile sakramentu chrztu świętego. Początkowy zamiar wzięcia przez cesarza rytualnej kąpieli we krwi niewinnych dzieci zainicjował kolejne zdarzenia i stał się źródłem zawikłań akcji. Decyzja cesarza była okazją do przedstawienia niezłomnych młodzieńców, gotowych ponieść śmierć dla dobra Konstantyna. Wymowne, że słowa o obowiązkach poddanych wobec władcy wypowiadają w tragedii właśnie osoby młode. Ich heroiczne deklaracje dowodzą, że wybór między miłością do rodziców a koniecznością poświęcenia się dla władcy jest oczywisty. Juliusz, syn dostojnika Metela, przykładowo porównuje cesarza do głowy, która kieruje innymi, podrzędnymi członkami ${ }^{64}$, a władzę monarchy zrównuje z władzą Boską:

Zdrowie cesarza krwi żąda

Rzymskiej. Głowa, gdy, ojcze, zaboli, czy inne

Członki, jeśli potrzeba, krwi żałują?

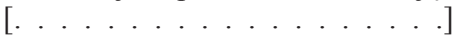

Gdy cesarze i życie chcą wydrzeć, czy słusznie

To czynią, czy niesłusznie, roztrząsać rzecz próżna,

Opierać się ich woli cale niebezpieczna,

Cesarzom jak i bogom, któż się bez swej szkody

Sprzeciwia? ${ }^{65}$

W tej samej tragedii Bielski włożył w usta młodzieńca pouczenie dla rodziców:

FLAWIUSZ

[...] Ach, ojcze, ach, Metelu, nie samym

Wiekiem długim szacujcie domów waszych chwałę,

Cnotą razem szacujcie. Dłużej żyć będziemy,

Gdy życie dla rodziców zdrowia położemy -

Żyć w pamięci, żyć w sercach ${ }^{66}$.

Pokazanie, że bohaterowie pozbawieni są dylematów, którymi obciążeni zostali ich ojcowie, to zabieg celowy. Właśnie młodzieńcy hołdowali idei obywatel-

${ }^{64}$ Porównanie państwa do organizmu ludzkiego, a władcy do głowy było dość popularnym motywem, chociażby w renesansowej publicystyce. Posłużyli się nim m.in. P. S k a r g a w Kazaniach sejmowych czy A. Fry c z Modrze w s k i w traktacie O poprawie Rzeczypospolitej.

${ }_{65}$ B i e $1 \mathrm{~s} \mathrm{k} \mathrm{i,} \mathrm{Konstantyn} \mathrm{Wielki,} \mathrm{pierwszy} \mathrm{chrześcijański} \mathrm{cesarz,} \mathrm{akt} \mathrm{II,} \mathrm{sc.} 3$.

${ }^{66}$ Ibidem, akt V, sc. 5. 
skiej, a racje przez nich wypowiadane tym łatwiej trafiały do uczniów zgromadzonych na widowni.

W ostatniej tragedii Bielskiego (Aleksy, cesarz wschodni) idea obywatelskości nabrała jeszcze innego wymiaru. Tytułowy Aleksy dobrowolnie zrezygnował z władzy za cenę uwolnienia ojca. Młodzieniec uosabiał postawę pogardy dla ziemskich wartości oraz bezgranicznej miłości synowskiej. Zbrojna agresja, której cel stanowiło oddanie tronu prawowitemu władcy, była - według niego - usprawiedliwiona. Przywrócenie praworządności i ładu w państwie warte były bowiem największych poświęceń.

Postaci młodzieńców z większości tragedii Bielskiego ukształtowane zostały zgodnie z popularnym od czasów antycznych toposem puer senex ${ }^{67}$. Dojrzałość sądów przekładała się także na wybór właściwej, zgodnej z duchem chrześcijańskim, drogi życiowej. W deklamacji Vocatio Divina dwóch przyjaciół, Probinius i Modestus (a więc o imionach znaczących), porzuca dworskie życie pod wpływem lektury historii o św. Antonim i wybiera żywot pustelniczy. To właśnie młodzi wypowiadają w sztuce sądy o nietrwałości władzy cesarskiej i bezzasadności zdobywania kolejnych zaszczytów. Przemawiają - wbrew swoim ojcom - z perspektywy dojrzałych osób. Ta ,zgodność przeciwieństw" ${ }^{68}$, a więc połączenie młodości i mądrości oraz niezwykłej charyzmy religijnej, wykorzystana została przez Bielskiego również w kreacji królewicza Leona z tragedii Niewinność zwycięża potwarzy. Bohater gotów był ponieść śmierć w imię obrony prawowierności, własnych ideałów i miłości ojcowskiej. Syn cesarza Bazylego został przedstawiony jako gorliwy wyznawca religii katolickiej, który gardzi zaszczytami, tronem oraz swoim życiem i dzięki temu ujawnia fałsz złych doradców króla, m.in. „,najszkodliwszego Kościołowi kacermistrza" Focjusza. Już w poprzedzającym sztukę argumencie młodość pobożnego bohatera została przeciwstawiona starości obłudnych starców:

Zwyciężyła niewinność włożona na młodzieńca pobożnego potwarzy, nie bez Nieba pomocy, które Leo młody szacował bardziej niż cesarstwo. Pohańbiona została kacerska zdrada, odkryta kacerzy obłuda [...]. Odnawiamy dzisiaj tryumf ten niewinności, czyli zwycięstwo Leona młodego i pobożnego nad starcami dwiema bezbożnymi, Focjuszem i Teodorem ${ }^{69}$.

Niezłomność i charyzma religijna oraz wierność doktrynie katolickiej połą-

${ }^{67}$ Zob. E. R. C u r t i u s, Literatura europejska i łacińskie średniowiecze. Przeł., oprac. A. B or o ws k i. Wyd. 3. Kraków 2009, s. 109-110. Warto przypomnieć, że topos puer senex wykorzystał Bielski także w swojej późniejszej mowie pochwalnej ku czci Andrzeja Młodziejowskiego. Przekształcił ten topos jednak i dostosował do sytuacji ofiarowania - otrzymania godności biskupiej przez dostojnika. Młodość połączył bowiem z dojrzałością duchową, religijną. Pisał J. B i e 1 s k i, Gratulatio [...] Andreae Stanislao Kostka Młodziejowski (Poznań 1768, s. 10): „nisi forte provectiores annos honor id circo expectaverit, ut suae ab illis authoritati novum accessisset ornamentum, cum senium unum si exemerimus, omnia in te matura senatu et publica expectatione digna pridem ac a primis prope sacerdotii annis comperiret [Gdyby zaszczyt 〈tj. otrzymanie sakry biskupiej〉 nie czekał na późne lata, aby przydać twej powadze nowej ozdoby, to wówczas, jeśli wykluczylibyśmy twoją starość, okazałoby się, że wszystkie rzeczy w tobie od dawna i niemal od pierwszych lat kapłaństwa są dojrzałe i zgodne z powszechnymi oczekiwaniami]". Dziękuję za pomoc w tłumaczeniu tej mowy paniom Roksanie Kielian, Annie Lenartowicz-Zagrodnej i Monice Szafrańskiej-Sienkiewicz.

${ }^{68} \mathrm{Curtiu}$ s, op. cit., s. 209.

69 J. B i e ls k i, Niewinność zwycięża potwarzy, czyli Leo VI cesarz. Poznań 1753. Bibl. PAN w Krakowie, rkps 729, s. 4-5. 
czone z młodością to także cechy bohaterów tragedii Apoloniusz, Chrystusów rycerz. Tytułowy bohater, syn dostojnika rzymskiego, to przykład postaci posągowej, niewzruszonej, która nie waha się oddać życia w imię miłości do Chrystusa. Akcja sztuki rozgrywa się w okresie prześladowań chrześcijan za czasów cesarza Dioklecjana. Jej fabuła oparta została na schemacie budującym (moralizatorskim). Miało to na celu uświadomienie odbiorcy, że dobro (pojmowane jako chrześcijańska cnota) opłaca się, a zło (czyli grzech) - nie ${ }^{70}$. Apoloniusz, postać cnotliwa, za wierność Chrystusowi oraz jawną niechęć do kultów pogańskich ponosi śmierć męczeńską i w wymiarze duchowym zostaje wynagrodzony (zbawiony). W usta tego „starego młodzieńca” Bielski kilkakrotnie wkłada żarliwe i niezwykle dojrzałe wyznania wiary. To mł ody Apoloniusz objaśnia cesarzowi sens dekalogu, a staremu ojcu uświadamia konieczność zachowania wierności własnym ideałom.

Bohaterowie zreformowanych tragedii jezuickich, w tym także utworów Bielskiego, byli osobami młodymi. To pozwalało identyfikować się widzom ze stawianą za wzór postacią ${ }^{71}$. Zamiast cudów wypełniała sztuki swoista analiza psychologiczna: bohaterowie wyrażali swoje wątpliwości i rozterki, a przez to zbliżali się niewątpliwie do młodej widowni. Co ważne, postawa religijna łączona była z patriotyczną, zgodnie z przekonaniem o współzależności obu postaw. Jednocześnie w relacjach rodzinnych ujawniały się uczucia czułości, zażyłości, które wpływały na tkliwe zakończenie tragedii. Mimo młodego wieku postaci ze zreformowanych tragedii były dojrzałe pod względem moralnym. W sytuacjach probierczych wykazywały się heroizmem, przedkładaniem obowiązku nad uczucie (zgodnie z cyceroniańskim ideałem obywatela), drogi męczeńskiej nad życie światowe i pełne zaszczytów. Ów celowo zastosowany kontrast dowodził, iż postawa taka jest możliwa do osiągnięcia ${ }^{72}$.

Wypowiedzi bohaterów tragedii Bielskiego, zawierające wykładnię moralną, często przybierały formę dłuższych monologów. Kwestie wygłaszane na scenie przez uczniów były bowiem przedłużeniem lekcji retoryki i wykorzystywały zdobyte przez nich umiejętności oratorskie ${ }^{73}$. W dramaturgii jezuickiej połowy XVIII w. modyfikacji uległy też dialogi postaci scenicznych. Rozmowy odzwierciedlały proces myślenia bohaterów, dlatego wyzyskiwały bogatą stronę argumentacyjną. Taki sposób oracji zmuszał, jak zauważył Tadeusz Bieńkowski, do „wyrobienia nawyków logicznego rozumowania": nawet jeśli sztuki miały charakter dydaktyczny, to owa moralistyka była odtąd umotywowana psychologicznie ${ }^{74}$. Również dialogi w tragediach Bielskiego odzwierciedlały proces myślowy postaci. Dzięki

${ }^{70}$ Zob. T. M i c h ało w s k a, Między poezją a wymowa. Wrocław 1970, s. 190-191.

${ }^{71}$ Zmianę tę widać wyraźnie w kreacji świętego, który od połowy XVIII w. stał się przykładem postaw młodzieńczych (np. św. Stanisław Kostka z tragedii W. M ę c i ń s k i e g o Drama o powotaniu św. Stanisława Kostki do zakonu Societatis Jesu 〈Przemyśl 1755〉).

72 Zob. KP 112-113; KW 16, 27. - B. J u d k ow i a k: JT 38; Wzgardzony wielogłos, s. 175; Klasycyzm w dramacie polskim XVI-XVIII wieku. W zb.: Klasycyzm. Estetyka, doktryna literacka, antropologia, s. 137.

${ }^{73} \mathrm{~K}$ a d u $1 \mathrm{~s} \mathrm{k} \mathrm{a} \mathrm{(KW} \mathrm{28)} \mathrm{jako} \mathrm{przykład} \mathrm{unowocześnionych} \mathrm{ćwiczeń} \mathrm{retorycznych} \mathrm{podała} \mathrm{Ć} \mathrm{wi-}$ czenie krasomówsko-prawne [...] Bielskiego, M. B. To p o $1 \mathrm{~s} \mathrm{k} \mathrm{a} \mathrm{(Bielski} \mathrm{Jan.} \mathrm{Hasło} \mathrm{w:} \mathrm{Wielkopol-}$ ski słownik biograficzny. Red. A. Gąsiorowski. Warszawa-Poznań 1981, s. 54) określiła zaś Bielskiego mianem „odnowiciela przestarzałej retoryki”.

${ }_{74}$ T. B i e ń k o w s k i, Motywy antyczne i ich funkcja w jezuickim dramacie szkolnym w Polsce. „Meander” 1961, nr 3, s. 163-164. 
zastosowaniu pytań retorycznych, wtrąceń oraz pauz autor pokazywał stopniowe dochodzenie bohatera do prawdy. Krótkie frazy (często w formie równoważników zdań lub konstrukcji z elipsą) odzwierciedlały zaś emocje bohaterów. Bielski w umiejętny sposób potrafił oddać rozterki i wyrzuty sumienia postaci. Przykładem może być monolog Lucila - byłego chrześcijanina, zdrajcy i intryganta - z tragedii Apoloniusz, Chrystusów rycerz:

\section{LUCIL}

Tobie nieśmiertelne dzięki,

Jowiszu! Chrystusowa, bo cóż mi równego

Przyniosła służba! [...]

[...] Jowiszowi

Dzisiaj Lucil zaczyna służyć: [...]

$[\ldots \ldots \ldots \ldots \ldots \ldots$

[...] ale - cóż, ach! za młot serce wali!

Co bodzie myśli za sztylet? odstępuję wiary?

Chrystusa się wyrzekam? zdradzam przyjaciela?

[. . . . . . . . . . . . . ]

Ociec, matka Lucila Chrystusowi służą!

Chrystusa odstepuje Lucil? nie łzy matki?

Nie miłość ojca? mojej bezbożności cugle

Założą? Co, patrz, czynisz? z ostatniego szczebla

Upadku kto się cofa, niewcześnie się cofa.

Złóż postrachy, Lucilu, którymi się brzydzi

Serce, zamysły pełnij: nowe, owszem, zbrodnie

Łącz do dawnych $[\ldots]^{75}$.

Słowa postaci unaoczniały często wewnętrzną walkę, która prowadziła do właściwych wyborów. Zdobywanie samoświadomości było w dramatach jezuity najczęściej momentem niezwykle emocjonalnym. Dzięki wykrzyknieniom, zakłócaniu logicznego toku zdania (inwersji), wtrętom oraz przerzutniom autor podnosił dynamikę przekazu:

\section{MINERWIN}

[...] Stygną gniewy?

Oczy odwracasz? Bledniejesz? Tak w braterskim sercu

Żal i miłość wygasły?

\section{KONSTANTYN}

Rozżarzasz gniew jeszcze,

Zginiesz. Żołnierze, Kata!... albo stójcie.

Minerwinie, daruję-ć życie, Dalmacego

Oddaj stryjowi.

\section{MINERWIN}

Oddaj równie ojcu syna,

Minerwinowi Jula, Metelowi Flawia.

\section{KONSTANTYN}

Syny mam wrócić? Wrócisz Dalmacego (albo

Gdzież mnie znowu unosi impet, jeszcze wściekłe

Wymartwię gniewy). Syna mam wrócić, którego

${ }^{75}$ B i e ls k i, Apoloniusz, Chrystusów rycerz, s. 15-16. 
Krew wylana jagody te rumieni? ${ }^{76}$

Krótkie repliki bohaterów, przypominające często stychomytię, ożywiały przekaz oraz sprawiały, że emocje postaci były realnie odczuwanym napięciem. Widać to np. w scenie z tragedii Niewinność zwycięża potwarzy, gdy Stefan, brat Leona skazanego niesłusznie na śmierć, ma zająć miejsce prawowitego spadkobiercy tronu:

\section{STEFAN}

Tęś radę przedtym dawał, tej słucham, nie zajrzę

Władzy cesarskiej bratu.

TEODOR

Teraz radę daję

Inszą: którym Bóg większe nad gmin w lat przymioty, Tym nie przystoi życie w poddańczym jarzmie

Prowadzić, a nie ściągać rąk do berła, które

Szczęście daje.

\section{STEFAN}

Korony nie chcę, którą daje

Szczęście, której nie daje cnota.

TEODOR

Cnotą

Rządzi fortuna, gdy ta każe - wiara, cnota, Prawa ustąpić winny i, gdy każe, zbrodnie

Podobać się powinny.

\section{STEFAN}

Dotąd bardziej cnotę

Kochałem niż fortunę i bardziej wraz brata.

Od miłości mię brata, od miłości cnoty

Fortuna nie odwiedzie.

TEODOR

Kogo winnym czyni

Fortuna, taż uwalnia od winy i zbrodnią

Nie jest, co ona każe. Idź za szczęściem, rządy

Gdy odzierzysz greckiego państwa, w ten czas błędu

Tego poprawisz cnotą ${ }^{77}$.

Owe celowe zabiegi autora widać najlepiej w przypadku sztuk rękopiśmiennych, na których Bielski najpewniej osobiście naniósł poprawki ${ }^{78}$. Dokonane zmiany miały zazwyczaj charakter stylistyczny (np. zmiana szyku, formy fleksyj-

${ }^{76}$ B i e $1 \mathrm{~s} \mathrm{k}$ i, Konstantyn Wielki, pierwszy chrześcijański cesarz, akt IV, sc. 7.

77 B i e ls k i, Niewinność zwycięża potwarzy, Bibl. Uniwersytetu Wileńskiego, rkps IV 11651/4, akt II, sc. 4.

${ }^{78}$ Dukt pisma niektórych tragedii oraz naniesionych poprawek przypomina charakter z listów Bielskiego. W rękopisach pozostają tragedie Vandamorillus, Konstantyn Wielki, Niewinność zwycięża potwarzy oraz Aleksy, cesarz wschodni. Najwcześniejsza tragedia jezuity, Vandamorillus, zachowała się, co prawda, w jednym egzemplarzu, ale zawiera liczne poprawki i skreślenia autora. Był to zapewne egzemplarz autorski, ,reżyserski” (zob. Bibl. Uniwersytetu Wileńskiego, rkps IV 11651/7). Sztuka o królewiczu Leonie dochowała się w dwóch manuskryptach: z Bibl. PAN w Krakowie (rkps 729) oraz z Bibl. Uniwersytetu Wileńskiego (rkps IV 11651/4). Tragedia o Aleksym wydana została

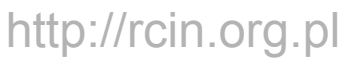


nej, leksemu). Niekiedy jednak autor przekształcał pierwotny tekst, aby uwypuklić jakieś słowo lub myśl czy też spotęgować emocje. Przykładowo: zmiana szyku w początkowej części wypowiedzi Flawiusza zwraca uwagę na chęć niewinnych młodzieńców do złożenia ofiary z własnego życia:

We rs a p i e r w o tna:
Jeżeliśmy niewinni, umrzeć
Za rodzice, które wina wikła,
Powinniśmy i owszem umrzeć

Gdy zaś przenosił Bielski na początek wersu epitety wartościujące, to akcentował $\mathrm{w}$ ten sposób zdanie bohaterów ${ }^{80}$. Celowym zabiegiem była też zamiana form bezosobowych na osobowe w zdaniach o charakterze oskarżeń. Dzięki temu adresaci wypowiedzi jawią się jako winowajcy ${ }^{81}$. Środki artystyczne nie tyle więc służyły Bielskiemu do popisu formalnego, ile raczej stanowiły nośnik dodatkowych sensów.

Ze względu na ważkość poruszanej tematyki dramaturdzy jezuiccy częściej wybierali tragedię niż w XVII wieku. Sam Bielski w liście dedykacyjnym do Władysława Szołdrskiego (z Zeyfadyna, króla Ormuzu) stwierdza, że tragedie zawsze były przypisywane wielkim mężom. Upamiętniały wydarzenia z życia książąt, królów i szlachetnie urodzonych ludzi. Uświetniały ich narodziny, zaślubiny czy zwycięstwa. Aby potwierdzić ową tezę, Bielski podaje m.in. przykłady intronizacji papieża Klemensa XII oraz Ludwika XV, podczas których przedstawiano inscenizacje tragedii. Wspomina również o ślubie cesarza Leopolda z arcyksiężną Klaudią. Wymienia następnie tragediopisarzy: Pierre'a Corneille'a, Pietra Metastasia i Pietra Pallavicina, dedykujących swoje tragedie znaczącym osobom. Wzmiankę na temat wysokiej rangi gatunku, który „powszechnie u wszystkich mądrych znajduje poważanie i między wszystkimi rymotwórstwa dziełami przodkowanie trzyma", powtórzył jezuita także później, w liście dedykacyjnym do Teodora i Joanny Nepomuceny Koźmińskich, dołączonym do tragedii Aleksy, cesarz wschodni. Trzeba przypomnieć, że w ramach wykładów poetyki uczniowie kolegiów jezuickich poznawali hierarchię gatunków literackich. Podniosłość tragedii korespondowała z celami wychowawczymi teatru szkolnego, pozwalała widzom na „kontemplację moralną” (JP 134) poruszanych na scenie zagadnień $\left(\right.$ JT 23) ${ }^{82}$. Taki wybór nie był więc przypadkowy. Trzeba, oczywiście, przypomnieć, że tragedia antyczna pojawiła się w teatrze jezuickim już w XVI wieku. Uznaniem

drukiem w Poznaniu, a jej rękopiśmienna wersja (która wyszła spod innej ręki) przechowywana jest w Bibl. Uniwersytetu Wileńskiego (rkps IV 11651/5).

79 J. B i e l s k i, Konstantyn Wielki, pierwszy chrześcijański cesarz, akt V, sc. 6. Bibl. Uniwersytetu Wileńskiego, rkps IV 11651/6. Podkreśl. M. M.

${ }^{80} \mathrm{~W}$ tragedii o Konstantynie Wielkim chrześcijanin Rufin wyraża opinię o bogach pogańskich i jednocześnie się od nich wyraźnie dystansuje: „Idomena / W a s z e g o ten był niegdyś czci bogów obrządek / G ł u p i, że na ofiarę bogom zabił syna” (ibidem, akt I, sc. 3; podkreśl. M. M.).

${ }^{81}$ Przykładem takiego zabiegu jest fragment tragedii Niewinność zwycięża potwarzy, gdy bezosobową formę ,zabito” zamienił Bielski na 2 os. 1. poj. Dzięki temu słowa wypowiadane przez cesarza Bazylego („Ach, mnie, cóż słyszę, syna zabiłeś!”) mają charakter oskarżenia Teodora o rzekome zgładzenie syna (akt V, sc. 3. Bibl. Uniwersytetu Wileńskiego).

${ }_{82}$ W wieku XVIII nauka o gatunkach odpowiadała klasycystycznej koncepcji literatury, na którą wpływała estetyka zarówno baroku, jak i klasycyzmu francuskiego. Zob. KZ 14-15; KP 96-97. 
cieszyły się zwłaszcza utwory Seneki, w których odnajdywano patetyczne monologi i zretoryzowane wypowiedzi chóru (P 200 $)^{83}$. Nie zawsze przestrzegano jednak klasycznych wyznaczników gatunkowych. Popularność na scenie kolegialnej zdobyły za to dramy oraz gatunki mieszane - tragikomedie czy komikotragedie. Miały one charakter dydaktyczno-utylitarny: unaoczniały pewne prawdy moralne. Dlatego w przedstawieniach z XVII w. tak ważną funkcję pełniła strona wizualna. Efekty sceniczne i natłok obrazów pobudzały wyobraźnię i dawały sposobność do współprzeżywania, ale zdominowały w końcu rolę słowa. Jednak poetyka i stylistyka baroku odpowiadały wymaganiom publiczności i stanowiły estetykę kultury wyższej. Obok planu ziemskiego w XVII-wiecznych sztukach ukazywano miejsca fantastyczne (zaświaty, rzeczywistość oniryczną itp.). Nierealność otoczenia powodowała brak precyzji w określeniu miejsca akcji, a tym samym rozluźnienie zależności przestrzenno-czasowych ${ }^{84}$. Na scenach XVII-wiecznych widzowie oglądali alegorie oraz konstrukcje symboliczno-emblematyczne (np. w intermediach z przedstawienia Societas Loiolana czy też ze sztuki Antoniego Strachwitza Syngareda paszkwilant ${ }^{85}$ ). Alegoryczność narzucała bierny odbiór spektaklu, a podręczniki pomagające odczytywać antyk za pomocą moralistyki chrześcijańskiej nie pozostawiały żadnych wątpliwości interpretacyjnych (KP 112).

Po reformie ta jednoznaczność uległa zmianie. Wymowa sztuk nadal była łatwa do odczytania, ale zamiast na zewnętrzną wystawność - położono nacisk na wypowiadane słowa. Sztuki przestały więc zadziwiać, aparatura sceniczna zaś służyła wyłącznie jako ułatwienie techniczne ${ }^{86}$. Ową zmianę można zaobserwować także na przykładzie tragedii Bielskiego. Jego twórczość dramatyczna wyraźnie ilustruje, że stał on na przełomie obu epok. Znajdują się w niej bowiem zarówno elementy klasycystyczne, jak i barokowe. Większość swoich dramatów wzbogacał jezuita intermediami ${ }^{87}$ - wzorem sztuk z poprzedniego stulecia. Kłóciło się to z praktyką drugiej połowy w. XVIII, gdyż odchodzono wówczas od tzw. części mniejszych (prologów, antyprologów, intermediów, epilogów). W dwóch wczesnych tragediach (Zeyfadyn, król Ormuzu i Tytus Japończyk) międzyakty zostały streszczone, natomiast w dramacie Niewinność zwycięża potwarzy jeden zapisano w całości. W innych przypadkach o występowaniu intermedium świadczyła tylko

${ }^{83}$ Zob. też JT 24; JP 138.

${ }^{84}$ Jak twierdzi W. R o s z k o w s k a (Główne ośrodki życia teatralnego w Polsce XVI i XVII w. W zb.: Z dziejów życia literackiego w Polsce XVI i XVII wieku. Red. H. Dziechcińska. Wrocław 1980, s. 102), dramaty jezuickie z XVII w. pisane były z myślą o natychmiastowej reakcji, zwłaszcza emotywnej. Zob. też KW 9-11. - R. P e lc z a r, Teatr $w$ kolegiach jezuickich na terenie diecezji przemyskiej w XVI-XVIII wieku. „Nasza Przeszłość” t. 87 (1997), s. 192.

${ }_{85}$ Societas Loiolana virtutis et sapientiae in Balthasare 〈?〉 Loyola iuvene [...]. Wilno 1708.

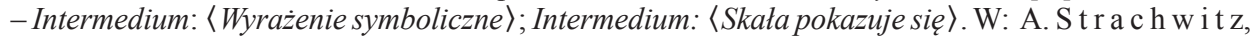
Syngareda paszkwilant, komedyjka [...]. Poznań 1757. Bibl. PAN w Krakowie, rkps 729, s. 428, 440. Wyd. I. K a d u l s k a, Formy intermediów sceny szkolnej połowy XVIII wieku. W zb.: Miscellanea z doby oświecenia. T. 6. Red. Z. Goliński. Wrocław 1982, s. 38.

${ }_{86}$ Zob. J. L e w a ń s k i, Teatry szkolne przed powstaniem Teatru Narodowego. W zb.: Teatr Narodowy w dobie oświecenia. Księga pamiatkowa sesji poświęconej 200-leciu Teatru Narodowego. Red. E. Heise, K. Wierzbicka-Michalska. Wrocław 1967, s. 161-164. Istotne było napomnienie generała W. Retza, który w 1763 r. uznał, że w urządzaniu przedstawień powinno być brane pod uwagę przede wszystkim dobro ucznia, a nie chęć popisywania się przed zacnymi gośćmi (KP 98).

${ }^{87}$ Intermediów brak tylko w drukowanej wersji tragedii Aleksy, cesarz wschodni. Zamieszczone zostały natomiast w rękopiśmiennej wersji tego dramatu. 
wspomniana na końcu aktu nazwa gatunku. Był to wyraz ogólniejszej tendencji, która części mniejsze (w tym też intermedia) traktowała dość lekceważąco. Streszczone międzyakty z tragedii Bielskiego miały charakter alegoryczny. Występowały w nich jeszcze rozwiązania typowo barokowe. Intermedia z tragedii o Zeyfadynie komentowały więc akcję sztuki na płaszczyźnie symbolicznej. Wykorzystywały motywy znane z w. XVII: budowanie na scenie obelisków i burzenie kolosów. Znajdujemy w nich także personifikacje i, tak częste w baroku, postaci Geniuszy. Również intermedia z dramatów Tytus Japończyk spełniały funkcję symbolicznego komentarza do akcji sztuki ${ }^{88}$. Były one ciekawe też pod względem widowiskowości. Na początku sztuki, po wykazie osób, pojawił się dopisek: „Intermedia odmianę proporcjonalną rzeczy mają". Wykorzystano w nich zatem aparaturę sceniczną (periakty, system telari) ${ }^{89}$. Podobnie w intermedium z tragedii Niewinność zwycięża potwarzy następowała „odmiana sceny”. Ruchomą dekorację wykorzystano zapewne także do przekształcenia dekoracji w początkowym akcie tragedii Konstantyn Wielki. Przed sceną pierwszą w didaskaliach zaznaczono, że rozpoczyna się ona „w gaju Jowiszowi poświęconym, gdzie się na perspektywę między wielkośnymi drzewami ołtarz Jowisza ukazuje". W początkowym fragmencie zwielokrotnione zostały środki wyrazu: tańcom pogańskich kapłanów towarzyszyły efekty w postaci „wielkiego ognia” i wzbijającego się w górę ,wonnego dymu”. W akcie IV tragedii Niewinność zwycięża potwarzy pojawił się dopisek, że scenie towarzyszyć będzie ,do koronacyi zgotowana pompa”. Polegała ona zapewne na zgromadzeniu na scenie większej liczby osób. Cesarz Bazyli zwracał się bowiem kolejno do panów, żołnierzy, dworzan i pospólstwa (gdy tymczasem zwykle w jednej scenie występowało najwyżej trzech bohaterów).

Choć wszystkie dramaty Bielskiego niosły określone przesłanie moralne, to akcja skupiała się wokół jednostki, głównego bohatera. To on był przyczyną, inspiratorem kolejnych wydarzeń, jak również czynnikiem wpływającym na świat przedstawiony. Oddziaływało to także na kształt formuł tytułowych, w których Bielski eksponował imiona postaci (wyjątek stanowi tragedia Niewinność zwycięża potwarzy). Była to zresztą ogólna tendencja w dramaturgii jezuickiej drugiej połowy XVIII wieku. W tytułach wskazywano głównego bohatera oraz dodawano określenia gatunkowe, co w XVII w. zdarzało się sporadycznie (np. W. Męciński: Muley Mahumet, król fezański, tragedia 〈Przemyśl 1756〉; Hermenegild, tragedia 〈Przemyśl 1761-1765〉; M. Strusiński, Cyrus poznany, tragedia 〈Płock 1762〉). Był to wyraz odwrotu od niejednorodności i wielości kryteriów gatunkowych utworów wystawianych w szkolnych teatrach ${ }^{90}$. W przypadku tragedii wymuszało to respektowanie klasycystycznej, pięcioaktowej formy oraz stopniowego rozwoju fabuły, zgodnie ze wskazówkami Macieja Kazimierza Sarbiewskiego ${ }^{91}$.

Kompozycja tragedii Bielskiego odpowiada nowym wzorom. Wszystkie sztu-

${ }^{88} \mathrm{~W}$ opisie intermedium drugiego zaznaczono, że „Symbolicznie wyraża [ono] Tyta różnymi o wiarę urzucanego przeciwnościami [...]”, w międzyakcie czwartym zaś, że pokazuje „Z okoliczności różnych w scenie przeszłej i przyszłej szczęścia odmian, Fortuny i życia niestałość [...]”" (B i e $1 \mathrm{~s} \mathrm{k} \mathrm{i,} \mathrm{Tytus} \mathrm{Japończyk,} \mathrm{s.} \mathrm{23,} \mathrm{46).}$

${ }^{89}$ Zob. m.in. Z. R a s z e w s k i, Z tradycji teatralnych Pomorza, Wielkopolski i Śląska. Wrocław 1955, s. 20-21.

90 Zmiana ta ułatwiała niewątpliwie odbiór sztuk - w nastroju wzniosłym przy tragedii, lekkim przy komedii (zob. KW 25; KP 111).

91 M. K. S a r b i e w s k i, O poezji doskonatej, czyli Wergiliusz i Homer (De perfecta poesi, phtp:ircin:org.pl 
ki składają się z pięciu aktów i respektują zasadę trzech jedności. Co prawda, kondensacja przedstawionych zdarzeń kłóciła się z zasadą prawdopodobieństwa, ale była to praktyka powszechna dla dramatów jezuickich z drugiej połowy XVIII wieku. Podobnie odejściem od klasycystycznych reguł tragedii było optymistyczne zakończenie. Ważna stawała się poruszana problematyka moralna, nie zaś końcowa katastrofa. Chodziło o pokazanie tryumfu bohatera i tym samym wiary katolickiej. Jasna kwalifikacja moralna, tj. potępienie niegodziwości i pochwała cnoty, nie wymagała nieszczęśliwego zakończenia (KZ 69-70) ${ }^{92}$. Praktyka ta zgadzała się z propozycjami niemieckiego jezuity, Franciszka Langa, który w swoim podręczniku gry aktorskiej postulował „wypogodzenie” tragedii, pozbawienie jej okropności i lęku ${ }^{93}$. Przykładem tragedii optymistycznej był już Jonatas Jaworskiego. Również tragedie Bielskiego unikają drastycznego rozwiązywania konfliktów. Wszyscy bohaterowie odnoszą sukcesy - dojrzewają do sprawowania funkcji monarchy, wyzbywają się fałszu i zdrady (Zeyfadyn, król Ormuzu), uzyskują nagrodę za swoją niewinność (Vandamorillus, Niewinność zwycięża potwarzy), są nieugiętymi wyznawcami Chrystusa i swym przykładem przeciągają innych na stronę chrześcijaństwa (Tytus Japończyk), po śmierci uzyskują zbawienie (Apoloniusz, Chrystusów rycerz), a także zwycięża w nich łaskawość i dobroć dla poddanych (król Ryszard z tragedii Vandamorillus oraz tytułowy bohater dramatu Konstantyn Wielki) itp. Owa zmiana w rozumieniu kategorii tragizmu odpowiadała zresztą późniejszym teoriom oświeceniowym (np. Golańskiego), w których tragizm łączył się ze wzruszeniem i tkliwością. Bohaterowie tragedii Bielskiego wielokrotnie wyznają swe uczucia synowskie, ojcowskie, braterskie czy przyjacielskie. Kwestie te są często przesycone ekstatycznym tonem, napisane w sposób ukazujący ogrom emocji, które przepełniają postaci. Żaden pozytywny bohater nie waha się też poświęcić własnego życia w imię obrony członka rodziny.

Optymistyczne rozwiązanie w dramatach jezuickich z drugiej połowy XVIII w. zwiększało siłę oddziaływania dydaktycznego: tryumfowała postawa aprobowana oraz bohater, który swym przykładem zachęcał i pociągał odbiorców ${ }^{94}$. Jednak w odróżnieniu od sztuk w. XVII - nowe tragedie propagowały postaci herosów, którzy działali dla dobra ogółu, gotowi byli poświęcić życie, aby ocalić ojczyznę. Wymowne są słowa Alcyma, jednego z bohaterów tragedii Bielskiego Aleksy, cesarz wschodni (akt I, scena 5), który wypowiada deklarację:

Którakolwiek płynie

W tych żyłach krew, nie płynie mnie, ale ojczyźnie

sive Vergilius et Homerus). Przeł. M. P 1 e z i a. Oprac. S. S k i m in a. Wrocław 1954, s. 469-471. BPP, B 4.

92 Według L e w ań s k i e g o (Teatry szkolne przed powstaniem Teatru Narodowego, s. 163164) „krwawa tonacja” charakteryzowała wiele ówczesnych sztuk, zatem stała się pewną konwencją. Zadanie dramaturgów polegało więc raczej na umiejętnym konstruowaniu i rozwiązywaniu węzła dramatycznego. Badacz zauważył: „Groźny dramat oprawiony jest w potężną osłonę refleksji moralnych, zamienia się w rozległy, nieco psychologizujący komentarz do owej ludobójczej intrygi”.

${ }_{93}$ F. L a ng, Rozprawa o sztuce scenicznej. Przeł. J. Golińs k a. „Dialog” 2001, nr 8, s. 167-175. Zob. też I. K a duls k a, Między sztuka wymowy a sztuka aktorska (o podręczniku Franciszka Langa SI). W zb.: Kultura żywego słowa w dawnej Polsce. Red. H. Dziechcińska. Warszawa 1989. - JP 139.

${ }_{94}$ Ilustrowało to według Kadulskiej (KZ 84; KW 28) zmianę w rozumieniu psychiki odbiorcy. Zob. też J u d k o w i a k, Klasycyzm w dramacie polskim XVI-XVIII wieku, s. 141. 
I Panu płynie; jeżeli państwa bezpieczeństwo,

Narodu chwała, granic całość każe, hojny

W szafunku jej-że będę.

$\mathrm{Na}$ scenach kolegialnych pojawił się zatem nowy typ bohatera - obywatel. Jeśli dramaturdzy czerpali inspiracje z tradycji antycznej, to wykorzystywali ją do ukazania konfliktów między własnymi ambicjami i żądzami a poczuciem obowiązku. Dlatego tak chętnie czynili bohaterami swych tragedii władców lub dostojników. Potwierdza to twórczość Bielskiego, który w każdym ze swych dramatów przyznał tym postaciom doniosłą rolę. I choć fabuła częstokroć nawiązywała do schematu moralitetowego, to nowością były intryga, rozbudowana akcja oraz uzasadnienie psychologicznych cech bohaterów. Nawet motywy antyczne służyły wychowaniu obywatelskiemu ${ }^{95}$. W podobny sposób wykorzystywano zresztą epizody historyczne. Przeszłość dostarczała wzorów postępowania patriotycznego i służyła szerzeniu postaw obywatelskich. Takie postępowanie wynikało z połączenia społecznej funkcji szkoły z realiami życia narodu i potrzebami państwa (KW 24). O ile motywów antycznych raczej nie spotykamy w tragediach Bielskiego, o tyle epizody $\mathrm{z}$ historii wykorzystywane były przez jezuitę jako umoralniające exempla. A więc prześladowania chrześcijan $\mathrm{z}$ epoki cesarza Dioklecjana dostarczyły materiału o dwóch niezłomnych młodzieńcach-męczennikach - Apoloniuszu i Filemonie (Apoloniusz, Chrystusów rycerz). Epizody z historii cesarstwa bizantyjskiego stały się kanwą tragedii o Konstantynie Wielkim, cesarzu Bazylim i jego synu Leonie (Niewinność zwycięża potwarzy) oraz Aleksym I Komenie i początku trzeciej wyprawy krzyżowej (Aleksy, cesarz wschodni). Tematykę do swych dramatów czerpał też jezuita z dziejów ewangelizacji krajów Bliskiego i Dalekiego Wschodu (Zeyfadyn, król Ormuzu oraz Tytus Japończyk). Wykorzystał również epizod z historii XIII-wiecznej Anglii o skromnym i wiernym Vandamorillusie, którego ułaskawił król Ryszard.

Dydaktyczne oddziaływanie tragedii rozszerzono w XVIII w. także o krąg czytelników. Zaczęto bowiem (obok znanych już wcześniej sumariuszy) publikować pełne teksty dramatów. Choć druki te trafiały raczej do klasztornych bibliotek i domów dostojników, rzadziej zaś do rąk szerokich rzesz odbiorców (KP 100), to jednak świadczyły o nowej tendencji, zakrojonej na dużą skalę. Widzowie byli postrzegani również jako czytelnicy - a ten dwojaki sposób odbioru tragedii (raz jako widowiska, innym razem w formie lektury) mógł przyczyniać się do intensyfikacji jej przesłania. Ilustrują to dobrze niektóre listy dedykacyjne Bielskiego, pomimo iż są, co oczywiste, podporządkowane konwencjom panegirycznym artes epistolandi. W epistole z tragedii o Zeyfadynie, skierowanej do Władysława z Szołdr Szołdrskiego, jezuita naświetlił zagadnienie wierności wobec przełożonego. Podał nawet analogie między bohaterem tragedii - Machometem (!), którego działania motywuje wierność wobec księcia, a dostojnikiem. O lekturowym odbiorze dramatów pisał zaś Bielski w liście do Koźmińskiego, adresata tragedii Apoloniusz, Chrystusów rycerz. Uzasadniając wybranie go na patrona dramatu wspominał

${ }_{95}$ Zob. B i eńk o w ski, Motywy antyczne i ich funkcja $w$ jezuickim dramacie [...], s. 32, 104-109. Podobne zdanie wyraził też P e l c z a r (op. cit., s. 184-185), dla którego wybór tematyki antycznej i historycznej miał na celu tworzenie „konglomeratu epizodów religijno-moralnych mających rozwijać cnoty chrześcijańskie w społeczeństwie oraz piętnować wady i występki”. 
o licznych dobrodziejstwach możnego. Jezuita życzył więc swej tragedii, aby ją czytali „wszyscy wszędzie i wiecznie”, by przyszłe pokolenia uzyskały w ten sposób dowody zacności Koźmińskiego ${ }^{96}$.

Treści ideowe zawarte $\mathrm{w}$ odnowionych dramatach jezuickich dostępne były zatem również odbiorcom, którzy nie uczestniczyli w przedstawieniach. Autor tragedii już nie tylko był ,dostawcą" tekstu ,scenicznego" (do odegrania na deskach teatralnych), ale stawał się pisarzem-dramaturgiem. Edycja dramatów dawała też, jak zauważyła Judkowiak, możliwość „lekturowego przygotowania publiczności” (JT 33) i była prostą konsekwencją nobilitacji słowa w teatrze (JP 137).

Trzeba przypomnieć, że obok dążeń reformatorskich w największych kolegiach jezuickich (Warszawie, Wilnie, Poznaniu, Lublinie i Kaliszu), w wielu prowincjonalnych ośrodkach wyznacznikiem dobrego smaku była nadal estetyka barokowa. Obowiązywała ona aż do czasu kasaty zakonu i powołania Komisji Edukacji Narodowej (KP 114). Ale nawet $\mathrm{w}$ dramatach $\mathrm{z}$ najważniejszych kolegiów prócz pierwiastków klasycystycznych występowały nadal rozwiązania znane z XVII wie$\mathrm{ku}^{97}$. Zabiegi te burzyły klasycystyczną zasadę jedności. Wiele dramatów kłóci się również z zasadą prawdopodobieństwa i ze zdrowym rozsądkiem, gdyż w ramach jednego dnia (jedność czasu) tragediopisarze gromadzili nadmierną liczbę zdarzeń (KZ 29 n.).

Także w tragediach Bielskiego można odnaleźć pozostałości po w. XVII (obecność postaci alegorycznych i sygnitywnych, wzbogacanie dramatów o prologi oraz intermedia, pisanie tragedii z myślą o wykorzystaniu techniki telari). Jednak twórczość autora Zeyfadyna, króla Ormuzu wyraźnie odzwierciedla proces zmian zachodzących w teatrze jezuickim. Bielski związany był z kolegiami w Rawie, Kaliszu, a zwłaszcza w Poznaniu. Kolegium poznańskie powołano z myślą o zwalczaniu ruchów reformacyjnych na ziemiach północno-zachodnich. Z czasem stało się ono największym, najliczniejszym i najlepiej wyposażonym zespołem szkolnym jezuitów w Polsce ${ }^{98}$. Dzięki swojej kilkunastoletniej działalności w tym środowisku Bielski miał możliwość uczestniczenia w procesie unowocześniania kolegium. Jako nauczyciel poetyki i retoryki wpływał na kształtowanie się świadomości nowych pokoleń. Był również autorem popularnego podręcznika geografii historycznej, w którym propagował wychowanie obywatelskie ${ }^{99}$. Jego słowa są przejawem szerokiej erudycji i oczytania. Trzeba zaznaczyć, że Bielski powszechnie uchodził za odnowiciela klasycznej łaciny i propagatora polszczyzny w teatrze szkolnym ${ }^{100}$. Opublikowanie niektórych tragedii Bielskiego wynikało z przekonania o ich literackiej wartości i stanowiło, być może, inspirację dla innych twórców,

96 J. B i e $1 \mathrm{~s} \mathrm{k} \mathrm{i,} \mathrm{list} \mathrm{dedykacyjny} \mathrm{do} \mathrm{T.} \mathrm{Koźmińskiego.} \mathrm{W:} \mathrm{Apoloniusz,} \mathrm{Chrystusów} \mathrm{rycerz,} \mathrm{k.} \mathrm{a} 3$ v.

97 Przykładowo, w tragedii Ludwik (Lublin 1747) zamieszczony został antyprolog, dramat Agapitus męczennik (Warszawa 1762) był poprzedzony prologiem, a tragedię Przeradzkiego o cesarzu Maurycjuszu zamykał epilog. Dramaty nadal urozmaicano też intermediami (np. w tragedii Puttkamera Abdalomin znalazły się międzyakty alegoryczno-taneczne).

98 Zob. P i e c hni k, Działalność jezuitów [...], passim. - R o s z k ow s k a, op. cit., s. 100. - J u dk o w i a k, Wzgardzony wielogtos, s. 147.

99 J. B i e ls k i, Widok Królestwa Polskiego. T. 1-2. Poznań 1763. Zob. też P u c how s ki: Nauczanie historii w polskich kolegiach jezuickich, s. 292; Jezuickie kolegia szlacheckie Rzeczypospolitej Obojga Narodów, s. 263-266.

${ }^{100}$ O Bielskim, który stał „na rozstaju dwu światów zakonu, konserwatywnego i postępowego”, pisał też K w i a t k ow s k i (op. cit., s. 59-60), choć ostatecznie wymienił jezuitę w jednym ciągu 
zwolenników niebarokowej estetyki. Jezuita był więc jednym z propagatorów nowej dramaturgii jezuickiej ${ }^{101}$.

\begin{abstract}
A bstract
MALGORZATA MIESZEK

(University of Lodz)

\section{JAN BIELSKI'S DRAMATIC WORKS \\ AGAINST THE CHANGES IN JESUITIC THEATRE IN $18^{\mathrm{TH}}$ CENTURY}

The article discusses Jan Bielski's dramatic works from the perspective of the changes that took place in Jesuitic schooling in mid $18^{\text {th }}$ century. The changes are revealed in his writing on a number of levels: ideological (accentuation of civic issues), compositional (return to classical 5 act structure, preserving the principle of three unities), and the construction of the world presented. The Jesuit modernises and adjusts the plot and protagonist creation to the needs of the new dramaturgy. Referring to language and style of Bielski's tragedy, we observe distinguisment of the Polish language. Since the Jesuit fringed upon two epochs, apart from classicistic elements, devices popular in baroque dramas (allegorical characters, dramas enriched with prologues and interludes, and writing the tragedy with resort to the technique of periaktori) also find their expression.
\end{abstract}

z Kwiatkiewiczem, Bystrzonowskim, Malczewskim, czyli, jak ich określił, przeciwnikami reform. Zob. też B e d n ar s k i, Bielski Jan, s. 61.

${ }^{101} \mathrm{~J} \mathrm{u} \mathrm{d} \mathrm{k} \mathrm{ow} \mathrm{i} \mathrm{a} \mathrm{k} \mathrm{(JP} \mathrm{128-129)} \mathrm{uznaje} \mathrm{nawet} \mathrm{Bielskiego} \mathrm{za} \mathrm{współtwórcę} \mathrm{tzw.} \mathrm{poznańskiej}$ szkoły dramatopisania, choć samo określenie (,szkoła poznańska”) jest umowne, gdyż ruchliwość zakonników stanowiła wtedy coś powszechnego. Autorka wysuwa tezę o istnieniu przed połową XVIII w. nowego sposobu pisania dramatów, który zapoczątkowano w Kaliszu, ale dominacja przypadła później Poznaniowi. Kolegium poznańskie było dobrze wyposażone, miało wykształconą kadrę naukową, a tamtejszy teatr wyrastał z bogatych wcześniejszych tradycji. W innym zaś miejscu badaczka podsumowuje: „Dramatopisarstwo profesorów poznańskich nabiera znaczenia w historii tragedii i komedii polskiej" (JT 40). 